\title{
Noachian-Hesperian geologic history of the Echus Chasma and Kasei Valles system on Mars: New data and interpretations
}

\author{
Mary G. Chapman ${ }^{\mathrm{a}, *}$, Gerhard Neukum ${ }^{\mathrm{b}}$, Alexander Dumke ${ }^{\mathrm{b}}$, Greg Michael ${ }^{\mathrm{b}}$, Stephan van Gasselt ${ }^{\mathrm{b}}$, \\ Thomas Kneissl ${ }^{\mathrm{b}}$, Wilhelm Zuschneid ${ }^{\mathrm{b}}$, Ernst Hauber ${ }^{\mathrm{c}}$, Veronique Ansan ${ }^{\mathrm{d}}$, \\ Nicolas Mangold ${ }^{\mathrm{d}}$, Philippe Masson ${ }^{\mathrm{e}}$ \\ ${ }^{a}$ Planetary Science Institute, Tucson, Arizona, USA \\ ${ }^{\mathrm{b}}$ Institute of Geosciences, Freie Universitaet Berlin, Germany \\ ' German Aerospace Center (DLR), Berlin, Germany \\ d LPGN, CNRS, Université Nantes, France \\ e IDES, CNRS, Université Paris Sud, Orsay, France
}

\section{A R T I C L E I N F O}

\section{Article history:}

Accepted 19 November 2009

Available online 19 January 2010

\section{Keywords:}

chasma

valles

hyperconcentrated

tindar

dendritic

\begin{abstract}
A B S T R A C T
New high-resolution datasets have prompted a mapping-based study of the 2500-km-long Echus Chasma and Kasei Valles system that utilizes geomorphic details, stratigraphic relations, and cratering statistics derived from the new datasets. Our results suggest that between the Hesperian and Amazonian Epochs on Mars (3.7 Ga to Recent) the study area was affected by at least 4 episodes of widespread volcanic activity and 4 periods of episodic fluvio-glacial activity. This paper discusses the Noachian to Hesperian $(>2.6 \mathrm{Ga}$ ) history of the study area, during which time in the Hesperian three of the volcanic episodes took place along with the first two episodes of fluvioglacial activity. Highlights of our new findings and refinements from this time period include (1) two ancient western floods sourced from Tharsis that occurred around 3.61 and $3.4 \mathrm{Ga}$ and carved the east-trending path of north Kasei Valles; (2) Uranius Dorsum with 58 aligned cones along its length that was emplaced in north Kasei around 3.6 Ga between these periods of early flooding; (3) possible ash deposits surrounding Echus Chasma, one of which contains narrow dendritic valley systems that may have been carved over a period of about 10,000 yr; and (4) evidence that suggests glaciers and near-surface ice may have contributed to erosion of local units.
\end{abstract}

(c) 2009 Elsevier B.V. All rights reserved.

\section{Introduction}

The largest of the circum-Chryse outflow channels is Kasei Valles. Kasei Valles heads at one of the Valles Marineris troughs: Echus Chasma. Echus Chasma is a 175-km-wide, 100-km-long, open-ended, flat-floored depression centered at latitude $1^{\circ} \mathrm{S}$, longitude $80^{\circ} \mathrm{W}$. North from Echus Chasma, Kasei Valles is nearly $2500 \mathrm{~km}$ long, extending about 1600 to latitude $20^{\circ} \mathrm{N}$, longitude $75^{\circ} \mathrm{W}$ (near the location of the "enigmatic" Uranius Dorsum ridge, whose origin has long been uncertain, see Chapman and Scott, 1989) where the valley turns abruptly east and continues for another $900 \mathrm{~km}$ to debouch into Chryse Planitia (Fig. 1).

Numerous mapping studies have included part or all of the Kasei Valles area (Milton, 1974; Scott and Carr, 1978; Scott and Tanaka, 1986; Chapman and Scott, 1989; Jöns, 1990, 1991; Chapman et al., 1991; Tanaka and Chapman, 1992; Rotto and Tanaka, 1995; Tanaka et al., 2005). Previous mapping indicated that (a) the chasma and valles system cut into Hesperian ridged plains material unit $\mathrm{Hr}$ and $\mathrm{Hsu}$ of the Lunae Planum, Tempe Terra and Syria Planum bounding plateaus;

\footnotetext{
* Corresponding author. Planetary Science Institute, 1700 E Fort Lowell, Suite 106 Tucson, Arizona, 85719-2395, USA. Tel.: +1 928213 9073; fax: +1 5206228060. E-mail address: mchapman@psi.edu (M.G. Chapman).
}

(b) the Kasei channel floor consisted of Hesperian plains Hchp or older channel floor material Hcch; (c) Echus Montes and Chaos were either mesas of wallrock material $H N u$ or chaotic material unit Hcth; and (d) Tharsis Montes Formation lava members At4 and At5 of Amazonian age covered large parts of the channel, with older, underlying member Ht2 embaying Tempe Terra north of this massive valley (Scott and Tanaka, 1986). [Tharsis Montes Formation member Ht3 does not occur within the study area.] Observations from Viking data sets indicated that both lava units At4 and At5 postdated flooding from Kasei Valles (Rotto and Tanaka, 1995). Flows from the older unit At4 were shown to have travelled east from a source in Tharsis and were mapped to cover most of the northern half of Kasei Valles, and the enigmatic northeast-trending ridge of Uranius Dorsum was included and mapped as presumably a thick part of a flow. Lava flows from the younger unit $A t 5$ flow were also shown to be sourced from Tharsis and mapped to cover most of the southern half of Kasei Valles to Echus Chasma. In order to avoid lengthy redundancy, for references to previous mapping results throughout the text the reader is referred to those mentioned in this paragraph.

Our study of this system was prompted by the availability of new high-resolution data from the Mars Express High Resolution Stereo Camera (HRSC) images and derived digital terrain models (DTMs), Mars Odyssey Thermal Emission Imaging System (THEMIS), Mars 


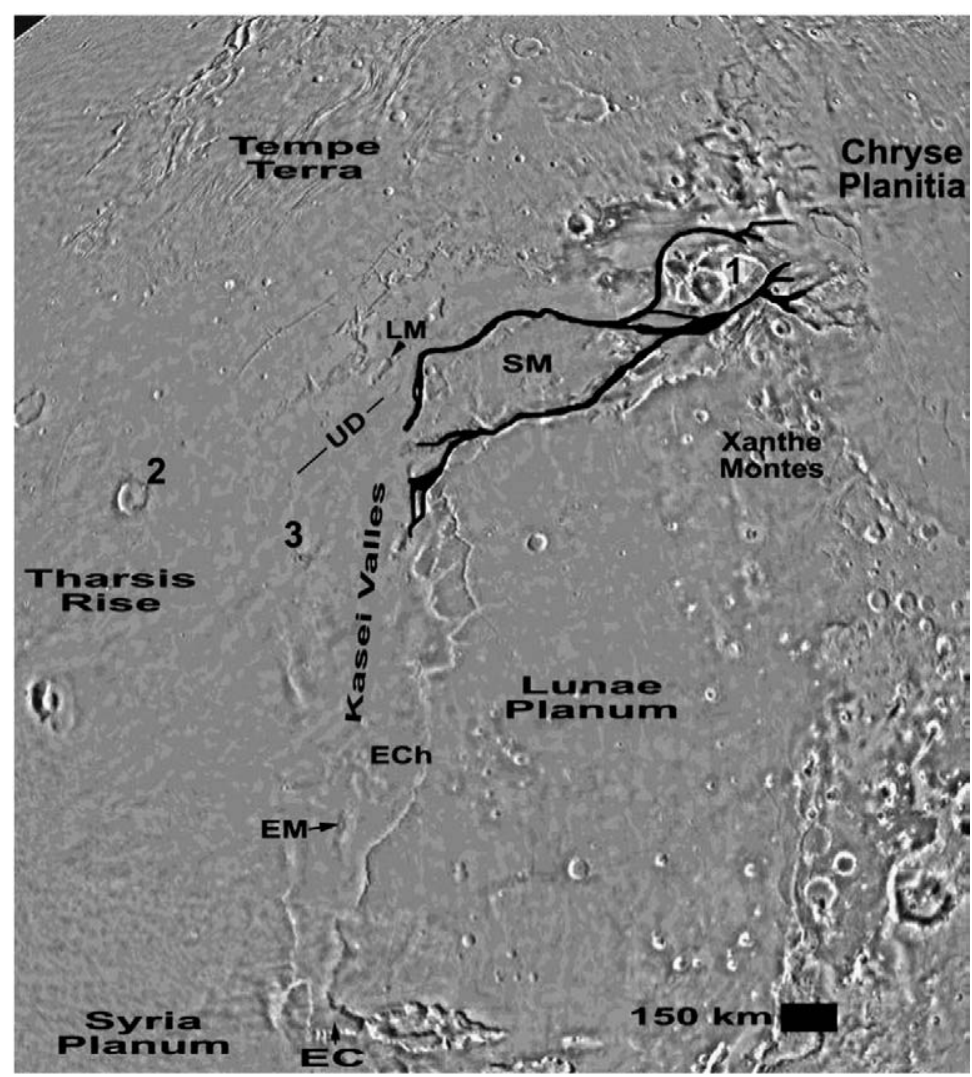

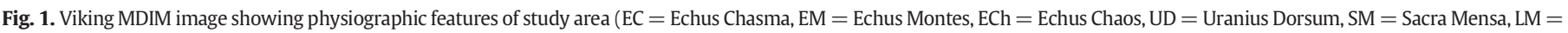

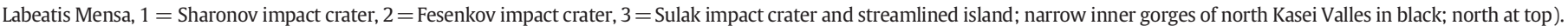

Orbiter Camera (MOC), Mars Orbiter Laser Altimeter (MOLA), Mars Reconnaissance Orbiter Context Imager (CTX), and Mars Reconnaissance Orbiter High Resolution Imaging Science Experiment (HiRISE). In order to understand the relations between source and channel, we undertook an integrated examination of this specific chasma-channel system using the new data sets and have produced a post-Viking revised map of the entire Echus Chasma-Kasei Valles system (Fig. 2).

The results of our mapping indicate that the Kasei Valles floods from Echus Chasma were predated in the northern (downstream) reaches of the channel by at least 2 older Early Hesperian floods sourced from the Tharsis Montes area, to the west of Tempe Terra. These older floods followed the trends of Tempe Terra rifts establishing the west-east trend of north Kasei Valles, and they likely cut down to the highest terraced floor elevation of north Kasei Valles. Formed after flooding carved the floor of this north section of Kasei, the Uranius Dorsum ridge consists of a chain of cratered cones that also follows the trend of Tempe Terra rift. Rather than being part of the Tharsis unit At4 (now designated as unit $\mathrm{Ht4}$ ) as previously mapped, this ridge (mapped as $\mathrm{Hud}$ ) is older and Hesperian in age. The subsequent Hesperian lavas from the Tharsis region (units $\mathrm{Ht} 2$ and $\mathrm{Ht} 4$ ) embayed Uranius Dorsum and flowed east toward Chryse Planitia, on a path down the valley cut by the Tharsissourced floods. In the Late Hesperian (to Early Amazonian period), geomorphic relations, both internal to volcanic flows of member $\mathrm{Ht} 4$ and between these flow and embayed mesas, indicate that areas of Kasei Valles may have been covered with surface ice and ice-rich materials. Around this time in the Hesperian and $800 \mathrm{~km}$ to the south, volcanic ash was being deposited around the Echus Chasma area and water was being released into the proto-Echus Chasma area via numerous narrow channels carved into the surface of the ash material on the Syria Planum plateau directly west and northwest of the chasma. Details of these units, the mapping, our new findings and interpretations follow in the rest of this brief overview. This paper is a summary of all Noachian to Hesperian units in the study area, each of which could merit a detailed paper.

\section{Methods}

To avoid data gaps, the mapping was digitally compiled on a highresolution shaded MOLA altimetry base. Complex areas were mapped in greater detail on individual HRSC images and compiled THEMIS mosaics and this linework was transferred to the altimetry base. Some map units correspond or are partly equivalent to units from previous mapping efforts, and the formal terminology of geologic units proposed by Scott and Tanaka (1986) and revised by Rotto and Tanaka (1995) was followed where feasible. However, in many places interpretations and contacts have been revised to reflect information visible on the new higher resolution data sets. The depths of some channels, thicknesses of some units, and heights of some streamlined islands were obtained in places using HRSC and MOLA altimetry profiles. The relative ages of geologic units and geomorphic features were established by observed stratigraphic relations and supported by new crater counts of surface materials using new high-resolution data. The ages of units were determined by over 200 crater counts of all craters with diameters $>1 \mathrm{~km}$ on areas of 15 HRSC orbital images (resolution approximately $17 \mathrm{~m} /$ pixel or m/p), $6 \mathrm{MOC}$ images (resolution typically about 1.5 to $3 \mathrm{~m} / \mathrm{p}$ ), and 11 THEMIS images (nominal resolution of $\mathrm{IR}=100 \mathrm{~m} / \mathrm{p}$ and $\mathrm{VIS}=18 \mathrm{~m} / \mathrm{p}$ ). Hesperian data are shown tabulated in this text (Tables 1-4). For these counts we used the production function coefficients of Ivanov (2001) and the cratering model of Hartman and Neukum (2001) to derive absolute ages; some ages were also taken from Werner (2006) who used the same methods. The geologic units yield 2 types of crater count data: a unit age that reflects the age of deposition and a resurfacing age that marks the age of erosion.

The cratering age of erosional units represent the time of their modification relative to other units whose statistical age and stratigraphic position in the sequence reflect their time of emplacement. Erosional units may thus consist of older material that is in place but has been highly modified by later processes (Milton, 1974). For example, 


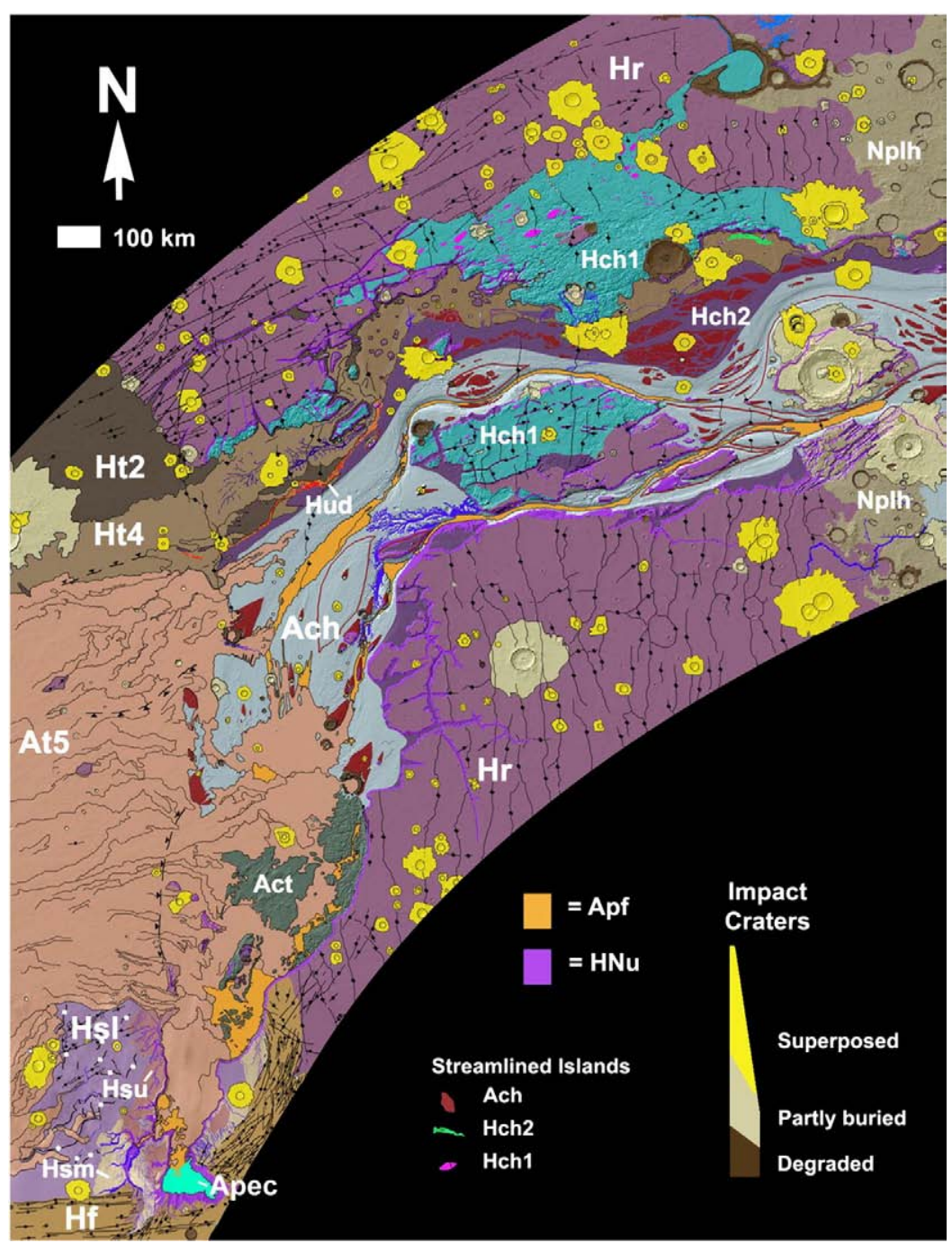

Fig. 2. Geologic map of the study area with unit designations.

flood units may not be depositional materials but mostly erosional units that date from periods of resurfacing. As with the Pleistocene Glacial Lake Missoula floods, each mapped flood unit may be the result of numerous individual floods closely spaced in time (Alt, 2001; Komatsu and Baker, 2007). On a final note, consistent with numerous studies (for example Christensen et al., 1998), volcanic flows in the area are all considered to be approximately basaltic in composition.

\section{Geologic history}

\subsection{Ancient pre-Kasei Valles Plateau materials}

The oldest rocks in the study area are Noachian-age rocks of the hilly unit Nplh. These materials outcrop on Lunae Planum and Tempe Terra abutting Chryse Planitia (Figs. 1 and 3). We agree with and use the age

Table 1

Crater count data for units $H r$, kipukas, and $H f$.

\begin{tabular}{|c|c|c|c|c|c|c|c|c|c|c|c|c|c|}
\hline \multirow[t]{2}{*}{ Unit } & \multirow[t]{2}{*}{ Imagery } & \multirow[t]{2}{*}{ Designation } & \multirow{2}{*}{$\begin{array}{l}\text { Area } \\
\left(\mathrm{km}^{2}\right)\end{array}$} & $\mathrm{N}(1)$ & Age & Error up & Error down & Error fit range & $\mathrm{N}(1)$ & Age & Error up & Error down & Error fit range \\
\hline & & & & \multicolumn{5}{|c|}{ Unit age } & \multicolumn{5}{|c|}{ Resurfacing age } \\
\hline \multirow[t]{3}{*}{$\mathrm{Hr}$} & HRSC & 1202.000 & 661.400 & 0.005 & 3.640 & 0.071 & 0.140 & $0.8 / 1.4$ & 0.001 & 1.250 & 0.110 & 0.110 & $0.2 / 0.45$ \\
\hline & HRSC & $1169,1158,1147$ & 1948.050 & 0.014 & 3.850 & & & & 0.001 & 2.980 & & & \\
\hline & HRSC & 1202.000 & 991.130 & 6.760 & 3.720 & & & & 0.001 & 2.000 & & & \\
\hline Average & & & & & $\overline{3.730}$ & & & & & $\overline{2.080}$ & & & \\
\hline \multirow[t]{4}{*}{ Kipukas } & HRSC & 2976.000 & 77.850 & 0.004 & 3.610 & 0.034 & 0.044 & $0.25 / 0.5$ & & & & & \\
\hline & THEMIS & I10563018 & 443.500 & & & & & & 0.003 & 3.460 & 0.050 & 0.074 & $0.35 / 1.2$ \\
\hline & THEMIS & V11786006 & 129.500 & 0.004 & 3.610 & 0.026 & 0.031 & $0.25 / 0.6$ & & & & & \\
\hline & MOC & E2100813 & 50.400 & & & & & & 0.002 & 3.190 & 0.200 & 0.690 & $0.24 / 0.6$ \\
\hline Average & & & & & 3.610 & & & & & $\overline{3.325}$ & & & \\
\hline \multirow[t]{3}{*}{$H f$} & HRSC & 920.000 & 3443.000 & 0.004 & 3.600 & 0.099 & 0.039 & $1.5 / 3.1$ & 0.001 & 1.830 & 0.21 & 0.21 & $0.36 / 1.1$ \\
\hline & MOC & R2000241 & 70.410 & & & & & & 0.000 & 0.467 & 0.004 & 0.004 & $0.13 / 0.3$ \\
\hline & MOC & S0300138 & 37.150 & & & & & & 0.000 & $\underline{0.190}$ & 0.025 & 0.025 & $0.06 / 0.2$ \\
\hline Average & & & & & 3.600 & & & & & $\overline{0.829}$ & & & \\
\hline
\end{tabular}

The underline marks the bottom of column of numbers that were used to obtain the average value. 
Table 2

Crater count data for units Hch1, Hud, Hsm, and gullies on unit Hud.

\begin{tabular}{|c|c|c|c|c|c|c|c|c|c|c|c|c|c|}
\hline \multirow[t]{2}{*}{ Unit } & \multirow[t]{2}{*}{ Imagery } & \multirow[t]{2}{*}{ Designation } & \multirow[t]{2}{*}{$\begin{array}{l}\text { Area } \\
\left(\mathrm{km}^{2}\right)\end{array}$} & $\mathrm{N}(1)$ & Age & Error up & Error down & $\begin{array}{l}\text { Error fit } \\
\text { range }\end{array}$ & $\mathrm{N}(1)$ & Age & Error up & $\begin{array}{l}\text { Error } \\
\text { down }\end{array}$ & $\begin{array}{l}\text { Error fit } \\
\text { range }\end{array}$ \\
\hline & & & & \multicolumn{5}{|l|}{ Unit age } & \multicolumn{5}{|c|}{ Resurfacing age } \\
\hline Hch1 & HRSC & $1169,1158,1147$ & 484.200 & .004 & 3.61 & 0.038 & 0.052 & $0.45 / 0.9$ & & & & & \\
\hline Hud (Uranius Dorsum) & HRSC & 1257.000 & 241.900 & .004 & 3.60 & 0.063 & 0.110 & .004 & & & & & \\
\hline \multirow[t]{6}{*}{$\mathrm{Hsm}$} & HRSC & 97.000 & 497.200 & & & & & & 0.000 & 0.263 & 0.093 & 0.093 & $0.3 / 0.5$ \\
\hline & HRSC & 920.000 & 2160.000 & .002 & 3.22 & 0.27 & 1.700 & $1.1 / 1.5$ & 0.001 & 1.170 & 0.5 & 0.5 & $0.6 / 1.1$ \\
\hline & MOC & R1003280 & 23.970 & & & & & & 0.000 & 0.010 & 0.0048 & 0.005 & $0.1 / 0.1$ \\
\hline & MOC & M0305517 & 25.520 & & & & & & 0.000 & 0.401 & 0.24 & 0.280 & $0.1 / 0.3$ \\
\hline & MOC & M0305517 & 47.000 & & & & & & 0.000 & 0.055 & 0.022 & 0.022 & $0.1 / 0.1$ \\
\hline & MOC & E1003204 & 42.390 & .004 & 3.61 & 0.11 & 0.11 & $0.5 / 0.6$ & 0.000 & $\underline{0.064}$ & 0.044 & 0.044 & $0.1 / 0.2$ \\
\hline Average & & & & & $\overline{3.42}$ & & & & & $\overline{0.312}$ & & & \\
\hline \multirow[t]{2}{*}{ Hud gullies (glacial erosion?) } & HRSC & 1257.000 & 288.500 & & & & & & 0.001 & 2.350 & 1.000 & 2.100 & $0.6 / 0.7$ \\
\hline & HRSC & 1257.000 & 230.800 & .002 & 3.40 & 0.17 & 1.500 & $0.6 / 0.8$ & & & & & \\
\hline
\end{tabular}

The underline marks the bottom of column of numbers that were used to obtain the average value.

Table 3

Crater count data for units Hch2, Ht3, and Ht4.

\begin{tabular}{|c|c|c|c|c|c|c|c|c|c|c|c|c|c|}
\hline \multirow[t]{2}{*}{ Unit } & \multirow[t]{2}{*}{ Imagery } & \multirow[t]{2}{*}{ Designation } & \multirow{2}{*}{$\begin{array}{l}\text { Area } \\
\left(\mathrm{km}^{2}\right)\end{array}$} & $\mathrm{N}(1)$ & Age & Error up & Error down & Error fit range & $\mathrm{N}(1)$ & Age & Error up & Error down & Error fit range \\
\hline & & & & \multicolumn{5}{|c|}{ Unit age } & \multicolumn{5}{|c|}{ Resurfacing age } \\
\hline \multirow[t]{5}{*}{ Hch2 } & HRSC & 3283.000 & 63.580 & .002 & 2.49 & 0.72 & 1.01 & $0.3 / 0.5$ & .000 & 0.59 & 0.11 & 0.11 & $0.1 / 0.2$ \\
\hline & HRSC & 3283.000 & 56.300 & .002 & 2.91 & 0.54 & 2.03 & $0.4 / 0.5$ & 7.06 & 0.12 & 0.02 & 0.02 & $0.1 / 0.2$ \\
\hline & HRSC & 3283.000 & 339.100 & .002 & 2.94 & 0.21 & 0.31 & $0.3 / 0.5$ & & & & & \\
\hline & HRSC & 1235.000 & 252.400 & .001 & 2.66 & 0.64 & 1.20 & $0.5 / 0.6$ & .001 & 1.05 & 0.17 & 0.17 & $0.2 / 0.4$ \\
\hline & HRSC & 1202.000 & 519.100 & .003 & 3.48 & 0.15 & 1.80 & $0.9 / 1.1$ & .001 & 1.58 & 0.14 & 0.14 & $0.2 / 0.6$ \\
\hline Inferred & Age $^{a}$ & & & & 3.4 & & & Average & Age & $\overline{0.84}$ & & & \\
\hline \multirow[t]{5}{*}{$\mathrm{H} 2$} & THEMIS & V14232007 & 867.612 & .003 & 3.02 & 0.442 & 2.498 & $0.8 / 1.0$ & 0.001 & 1.001 & 0.103 & 0.121 & $0.2 / 0.6$ \\
\hline & THEMIS & V14232007 & 647.059 & .004 & 3.36 & 0.110 & 0.487 & $0.6 / 0.9$ & 0.001 & 1.809 & 0.145 & 0.145 & $0.2 / 0.5$ \\
\hline & THEMIS & V13608009 & 431.542 & .009 & 3.67 & 0.094 & 0.326 & $0.9 / 1.9$ & 0.001 & 1.015 & 0.153 & 0.186 & $0.2 / 0.6$ \\
\hline & THEMIS & V13608009 & 788.177 & .003 & 3.40 & 0.167 & 1.953 & $0.7 / 1.1$ & 0.000 & 0.781 & 0.071 & 0.073 & $0.2 / 0.4$ \\
\hline & HRSC & 1235.000 & 2006.000 & .018 & 3.89 & 0.083 & 0.210 & $0.9 / 1.9$ & 0.001 & 1.760 & 0.23 & 0.23 & $0.3 / 0.8$ \\
\hline Average & & & & & $\overline{3.38}$ & & & & & $\overline{1.15}$ & & & \\
\hline \multirow[t]{10}{*}{$\mathrm{Ht} 4$} & THEMIS & V14232007 & 924.390 & .004 & 3.43 & 0.171 & 2.625 & $0.9 / 1.3$ & 0.001 & 0.995 & 0.106 & 0.126 & $0.2 / 0.7$ \\
\hline & THEMIS & V13608009 & 1002.130 & .002 & 3.06 & 0.331 & 1.546 & $0.6 / 1.1$ & 0.001 & 1.054 & 0.099 & 0.104 & $0.2 / 0.5$ \\
\hline & HRSC & 3283.000 & 341.598 & .004 & 3.47 & 0.129 & 1.040 & $0.6 / 0.8$ & 0.001 & 1.012 & 0.151 & 0.154 & $0.2 / 0.4$ \\
\hline & HRSC & 3283.000 & 585.289 & .003 & 3.32 & 0.191 & 1.758 & $0.6 / 0.9$ & 0.001 & 1.136 & 0.136 & 0.147 & $0.2 / 0.5$ \\
\hline & HRSC & 1257.000 & 183.200 & & & & & & 0.001 & 1.580 & 0.360 & 0.360 & $0.3 / 0.5$ \\
\hline & HRSC & 1257.000 & 470.000 & .003 & 3.56 & 0.098 & 0.340 & $0.7 / 1.5$ & 0.000 & 0.781 & 0.160 & 0.160 & $0.3 / 0.5$ \\
\hline & HRSC & 71.000 & 1143.400 & .002 & 3.42 & 0.120 & 0.510 & $0.7 / 1.4$ & 0.001 & 1.080 & 0.120 & 0.120 & $0.3 / 0.5$ \\
\hline & HRSC & 3283.000 & 322.245 & .002 & 3.26 & 0.172 & 0.714 & $0.4 / 0.5$ & 0.001 & 1.041 & 0.156 & 0.161 & $0.2 / 0.3$ \\
\hline & HRSC & 1257.000 & 288.500 & & & & & & 0.001 & 2.350 & 1.000 & 2.100 & $0.6 / 0.7$ \\
\hline & HRSC & 1257.000 & 230.800 & .002 & 3.40 & 0.170 & 1.500 & $0.6 / 0.8$ & & & & & \\
\hline Average & & & & & $\overline{3.36}$ & & & & & 1.16 & & & \\
\hline
\end{tabular}

The underline marks the bottom of column of numbers that were used to obtain the average value.

a Inferred age based on stratigraphic relations.

relations and designation for unit Nplh that were established in previous studies. Kasei Valles has cut through these ancient heavily cratered materials near its terminus. Other Noachian materials likely crop out where plateaus are deeply eroded and older strata are exposed in wall rocks, on the Kasei Valles floor within streamlined islands, and in Echus Montes and Chaos. These areas are designated as Hesperian-Noachian material, undivided or unit $\mathrm{HNu}$ (Fig. 3). Noachian materials may also be exposed in impact crater rims and ejecta.

Table 4

Crater count data for narrow valleys in unit $\mathrm{Hsm}$ and unit $\mathrm{Hsu}$.

\begin{tabular}{|c|c|c|c|c|c|c|c|c|c|c|c|c|c|}
\hline \multirow[t]{2}{*}{ Unit } & \multirow[t]{2}{*}{ Imagery } & \multirow[t]{2}{*}{ Designation } & \multirow{2}{*}{$\begin{array}{l}\text { Area } \\
\left(\mathrm{km}^{2}\right)\end{array}$} & $\mathrm{N}(1)$ & Age & Error up & Error down & Error fit range & $\mathrm{N}(1)$ & Age & Error up & Error down & Error fit range \\
\hline & & & & \multicolumn{5}{|c|}{ Unit age } & \multicolumn{5}{|c|}{ Resurfacing age } \\
\hline \multirow{5}{*}{$\begin{array}{l}\text { Narrow } \\
\text { valleys } \\
\text { in Hsm }\end{array}$} & HRSC & 3283.000 & 63.580 & .002 & 2.49 & 0.72 & 1.01 & $0.3 / 0.5$ & .000 & 0.59 & 0.11 & 0.11 & $0.1 / 0.2$ \\
\hline & HRSC & 3283.000 & 56.300 & .002 & 2.91 & 0.54 & 2.03 & $0.4 / 0.5$ & 7.06 & 0.12 & 0.02 & 0.02 & $0.1 / 0.2$ \\
\hline & HRSC & 3283.000 & 339.100 & .002 & 2.94 & 0.21 & 0.31 & $0.3 / 0.5$ & & & & & \\
\hline & HRSC & 1235.000 & 252.400 & .001 & 2.66 & 0.64 & 1.20 & $0.5 / 0.6$ & .001 & 1.05 & 0.17 & 0.17 & $0.2 / 0.4$ \\
\hline & HRSC & 1202.000 & 519.100 & .003 & 3.48 & 0.15 & 1.80 & $0.9 / 1.1$ & .001 & 1.58 & 0.14 & 0.14 & $0.2 / 0.6$ \\
\hline \multirow{6}{*}{$\begin{array}{l}\text { Inferred } \\
\text { Hsu }\end{array}$} & Age $^{a}$ & & & & 3.4 & & & & & $\overline{0.84}$ & & & \\
\hline & THEMIS & V14232007 & 867.612 & .003 & 3.02 & 0.442 & 2.498 & $0.8 / 1.0$ & 0.001 & 1.001 & 0.103 & 0.121 & $0.2 / 0.6$ \\
\hline & THEMIS & V14232007 & 647.059 & .004 & 3.36 & 0.110 & 0.487 & $0.6 / 0.9$ & 0.001 & 1.809 & 0.145 & 0.145 & $0.2 / 0.5$ \\
\hline & THEMIS & V13608009 & 431.542 & .009 & 3.67 & 0.094 & 0.326 & $0.9 / 1.9$ & 0.001 & 1.015 & 0.153 & 0.186 & $0.2 / 0.6$ \\
\hline & THEMIS & V13608009 & 788.177 & .003 & 3.40 & 0.167 & 1.953 & $0.7 / 1.1$ & 0.000 & 0.781 & 0.071 & 0.073 & $0.2 / 0.4$ \\
\hline & HRSC & 1235.000 & 2006.000 & .018 & 3.89 & 0.083 & 0.210 & $0.9 / 1.9$ & 0.001 & 1.760 & 0.23 & 0.23 & $0.3 / 0.8$ \\
\hline Average & & & & 3.47 & & & & & 1.15 & & & & \\
\hline
\end{tabular}

The underline marks the bottom of column of numbers that were used to obtain the average value.

a Inferred age based on stratigraphic relations. 
We adopt and also agree with previous mapping results that indicated the chasma and valles system cut into Hesperian ridged plains material unit $\mathrm{Hr}$ of the Lunae Planum and Tempe Terra high plateaus (Fig. 3). Unit $\mathrm{Hr}$ delineates the base of the Hesperian System (Scott and Carr, 1978). Our new crater density counts of the unit $\mathrm{Hr}$ indicate the average age of emplacement to be around $3.73 \mathrm{Ga} \pm 0.2$ (Werner, 2006; Table 1). Thus the age of emplacement for the unit straddles the Upper Noachian-Lower Hesperian boundary, exactly the same position as found by crater counts of older Viking (Scott and Carr, 1978) to Mars Global Surveyor data sets (Tanaka et al., 2003, 2005). Unit $\mathrm{Hr}$ or Hesperian ridged plains material has long been interpreted to be widespread layered flood basalts akin to those that comprise the Columbia River Plateau of northwest America (Scott and Carr, 1978; Scott and Tanaka, 1986). This relatively smooth material, which has rare lobate flow fronts, is named for the well-known wrinkle ridges that mark its surface. The $\sim 3.7 \mathrm{Ga}$ flood basalt event that formed unit $\mathrm{Hr}$ is the first known widespread volcanism episode to take place in the Kasei Valles area. Two mound-shaped, fractured kipukas of material that date from the same age range are located on the east flank of Tharsis, just west of the Kasei Valles channel (Fig. 3; Table 1). The kipukas, which we mapped as material of unit $\mathrm{Hr}$, are embayed by young Tharsis lavas (unit At5, see below). Their rounded shapes and possible vent fractures led us to suggest that the kipukas may be remnants of low shields that could have been sources for some of the ridged plains volcanic flows.
Within the study area, Hesperian fractured material $(H f)$ is a localized unit of closely spaced graben surrounding Echus Chasma. Other grabens of about the same age are distributed throughout the study area, with the least amount of fractures occurring on Lunae Planum. The $\mathrm{Hf}$ unit was interpreted as lava material of unit $\mathrm{Hr}$ whose fractures relate to the formation of Valles Marineris, and hence Echus Chasma (Fig. 4; Scott and Tanaka, 1986; Witbeck et al., 1991; Rotto and Tanaka, 1995). The plateau graben appear to encircle Echus Chasma and the headwater area of Kasei Valles on Lunae and Syria Plana; however the wallrock boundaries of the Echus Chasma and Kasei Valles system are cut into unit $\mathrm{Hf}$ on these surrounding plateaus (Fig. 4). Therefore the graben may have been associated with a proto-depression in this area, but they predate the current configuration of the chasma as it has been modified and eroded back from its original extent. Subsidence and collapse of this depression would have formed a void that could easily have ponded water. New data indicate that fracturing took place in the Early Hesperian (3.60 Ga \pm 0.1 ), with reactivation of faulting in the Amazonian at the time of widespread late volcanism from Tharsis and Echus Chasma (1.8 Ga to $190 \mathrm{Ma}$ ). Because unit $\mathrm{Hf}$ graben became tectonically active in the Hesperian and resurfacing ages indicate likely tectonic reactivation of the faults in the Amazonian, the cross-cutting stratigraphic relations, and hence relative ages, are difficult to ascertain between units $\mathrm{Hf}$ and $\mathrm{Hr}$, but as the average absolute crater age of $H f$ is about that of unit $H r$, we interpret unit $H f$ as fracturing of unit $\mathrm{Hr}$ rocks, as have previous workers.

Our study indicates that the Kasei Valles floods from Echus Chasma were predated in the northern (downstream) reaches of the channel by

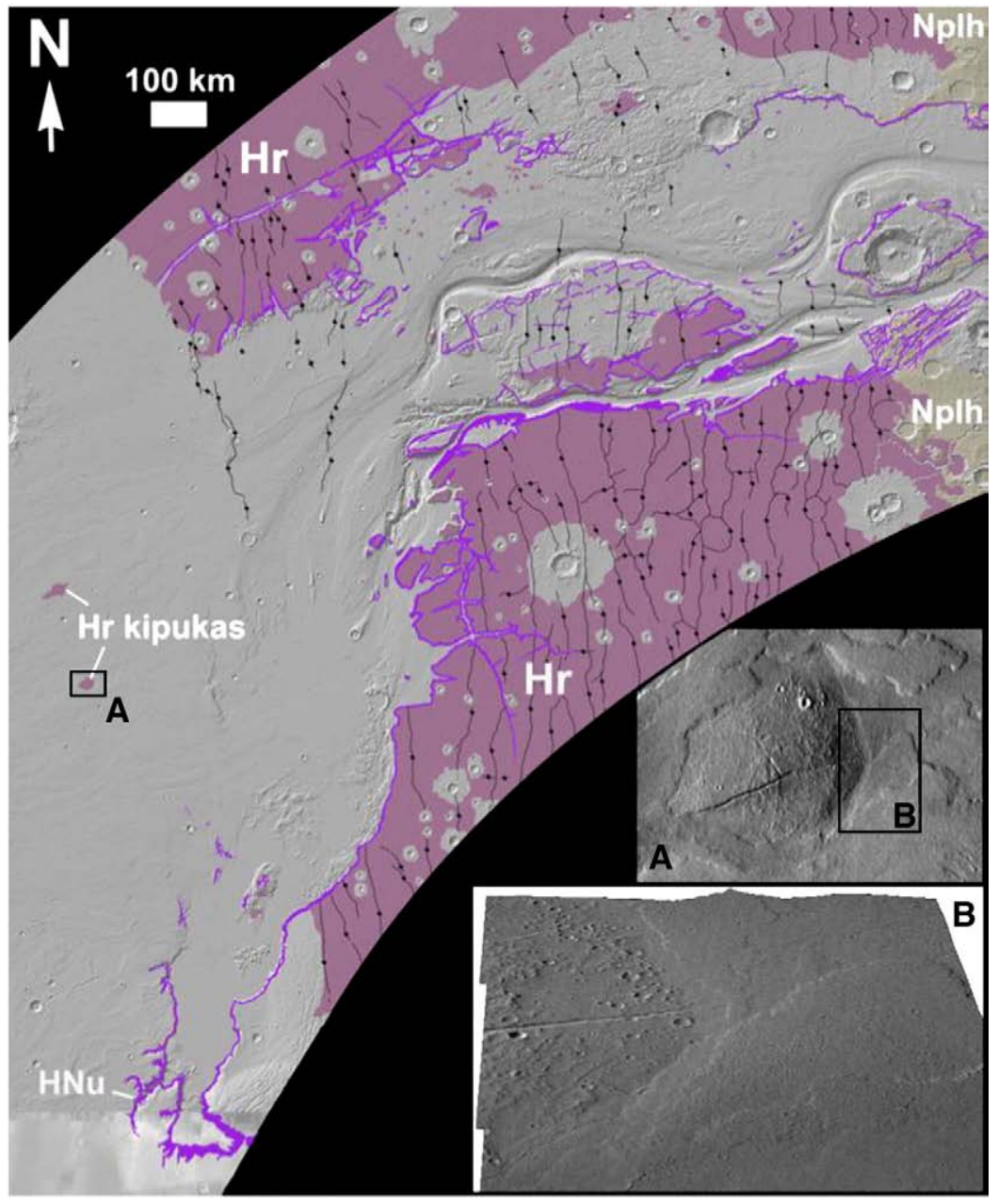

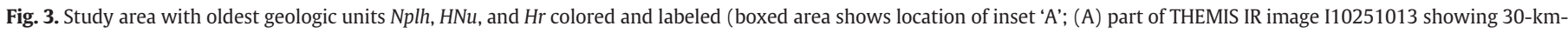

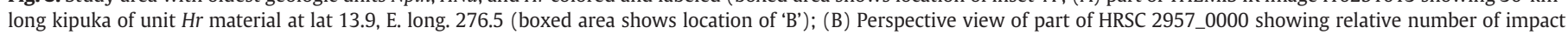
craters between same kipuka and younger embaying lava flows (unit At5). 
at least 2 older floods sourced from the Tharsis Montes area. The first flood episode in the early Hesperian is mapped as Hesperian channel unit 1 (Hch1), an erosional unit that affected the high plateau area of Tempe Terra (Figs. 1 and 5), in addition to Sacra Mensa and other plateau remnants. The eroded plateau areas are rough and contain numerous degraded streamlined islands, chains of pits, and grooves (Fig. 6A). The average absolute cratering age for this resurfacing unit is $3.61 \mathrm{Ga} \pm 0.4$ (Table 2). Ancient east-trending grooves and streamlined islands that predate the main Kasei floods were known to have cut Labeatis and Sacra Mensae, remnants of high plateau material in north Kasei at about $25^{\circ} \mathrm{N}$ (Fig. 1; Chapman et al., 1991; Tanaka and Chapman, 1992). This erosion was suggested to come from floods sourced to the west by Sacra Fossae and Tharsis, rather than the south from Echus, the source of later and main Kasei floods. New high-resolution data support the findings of these early reports, and also indicate plateau erosion of Tempe Terra by floods. HRSC topographic measurements indicate that the streamlined islands reach heights of $50-100 \mathrm{~m}$ on Tempe Terra, a plateau that is at least $1 \mathrm{~km}$ above the Kasei channel floor. On west Tempe Terra, some of the proximal flood erosion can be traced to a Labeatis Fossa, one of the large Sacra Fossae rifts later filled by younger lavas (Fig. 5), indicating that the floods likely followed the trends of the Tempe Terra rifts and graben and therefore had a source west of Tempe Terra, somewhere in the north Tharsis Montes area. The island heights and locations indicate that the ancient western floods from Tharsis were voluminous. However the lack of a clear channel boundary suggests that the widespread floods may have initially behaved as unconfined sheet flows. We trace a small part of the distal flood unit to a debouchment area in an ancient large (105-kmdiameter) impact crater basin on Tempe Terra where a rough-textured deposit with lobate terminations infills the crater floor (Fig. 6B). Within the crater, the material's lack of volcanic characteristics (internal pressure ridges and flow fronts) and its association with the track of the flood erosion lead us to suggest that the observed deposit may be laharic muds and that the flood could have evolved from catastrophic to hyperconcentrated flow along its northern route across Tempe Terra to the large impact basin. Floor grooves may indicate erosion by either catastrophic floods or glacial erosion, as similar-appearing features occur within catastrophically flooded and glacially eroded areas on Earth (Baker and Milton, 1974; Lucchitta, 1982; Kehew, 1982). Although these floods began on the high plateau area, $1.0 \mathrm{~km}$ above the Kasei Valles floor, the trends of many easternmost streamlined islands indicate that much of the floodwaters eventually become focused in the north (easttrending) valley of Kasei Valles to finally empty into Chryse Planitia, hence these ancient floods may have initially established the west-east trend of north Kasei Valles. Later stages of this flooding may have carved out most of the north Kasei Valles floor. This material marks the first widespread fluvio-glacial episode within the study area.

\subsection{Early proto-Kasei Valles materials}

After the formation of the ancient plateau materials, initial erosion of the east-trending part of north Kasei Valles, and faulting that

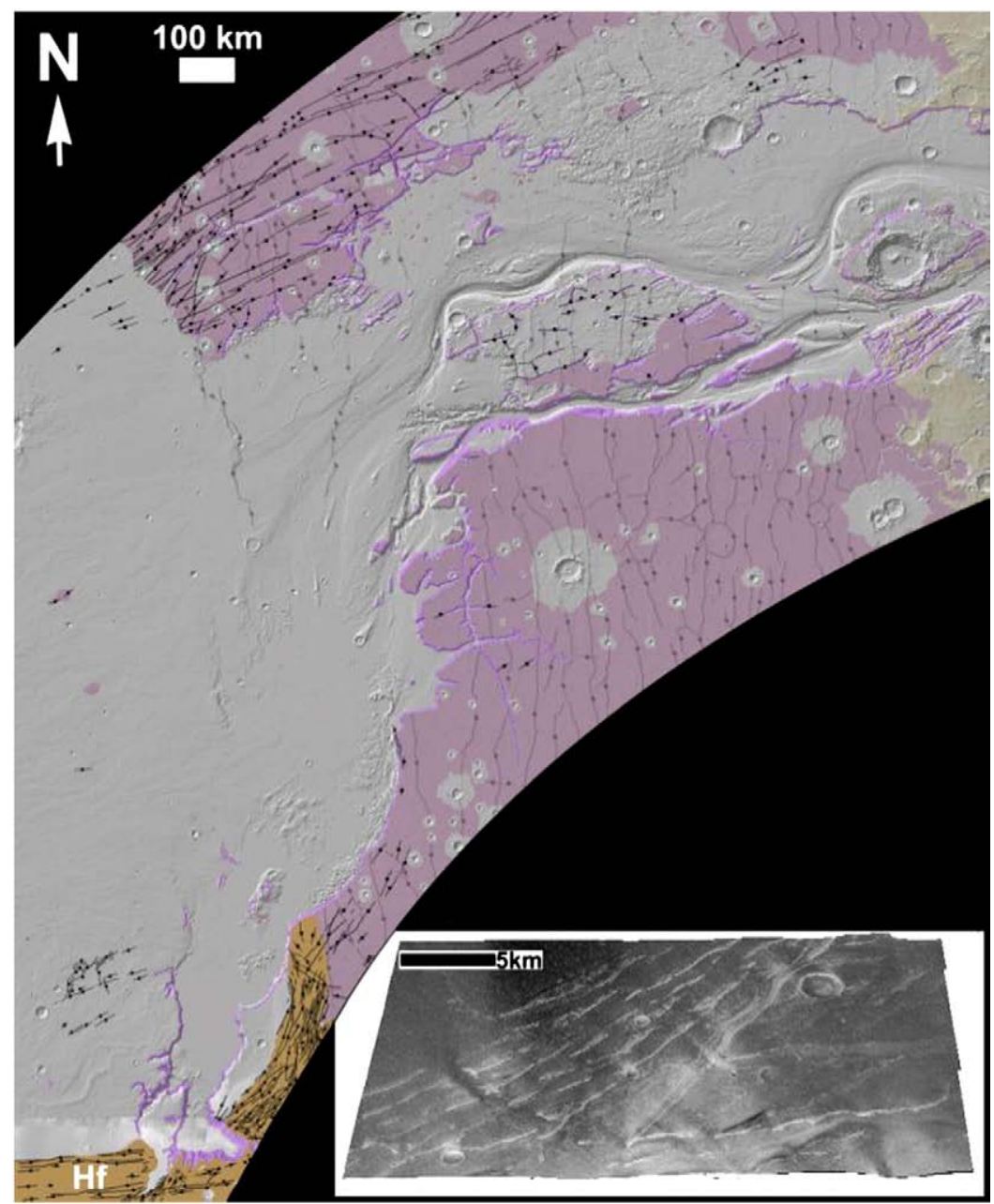

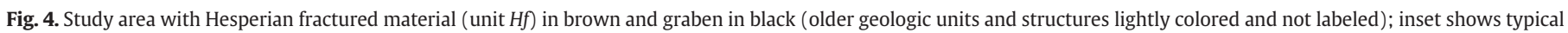
unit $H f$ characteristics on partial HRSC image 2204_0000 perspective view, located west of Echus Chasma at about lat. $-2.0^{\circ}$ and east long. $278.6^{\circ}$. 


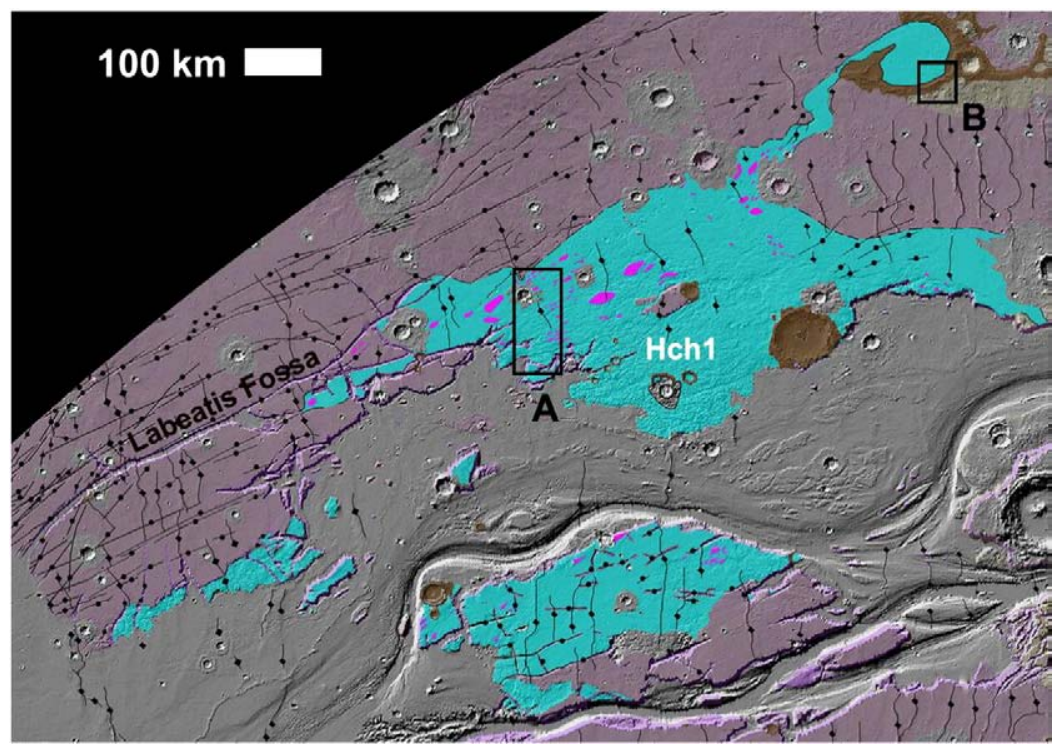

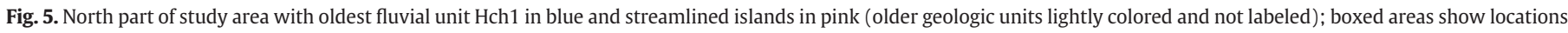
of images in Fig. 6).

formed the Echus Chasma depression, deposition within the map area occurred mostly on the flanks of Tharsis Montes and within the floor area of north Kasei Valles. The oldest material from this second series of deposits is located on the floor of the newly eroded, $3.6 \mathrm{Ga}$ west section of north Kasei and composes the over 600-km-long Uranius Dorsum ridge (Figs. 1 and 7). New crater counts indicate that Uranius Dorsum dates from $3.6 \mathrm{Ga} \pm 0.11$ (Table 2). This northeast-trending "enigmatic" ridge consists of a chain of cones (or mounds) and surrounding material here mapped as unit Hud (Fig. 7). The dorsum has 58 aligned cones along its length, each with a central pit. Most pits were elongated perpendicular to the ridge by erosion. Some cones have nested pits and one shows material possibly extending away from its pit (Chapman et al., 2008). Our mapping plots the easttrending enigmatic ridge of Uranius Dorsum to extend $2^{\circ}$ farther west
(120 km; to long. $80^{\circ} \mathrm{W}$.) than previously mapped by Rotto and Tanaka (1995). This new extension places the west extent of the ridge to lie beyond and west of the Kasei Valles floor on the distal flanks of Tharsis Montes. The ridge follows the trend of the Tempe, Mareotis, and Sacra Fossae rift systems that occur around the north end of Tharsis on Tempe Terra and north Lunae Planum (Tanaka et al., 1991; Hauber and Kronberg, 2001). The implication of pitted cones and the fossae-matching trend is that ridge origin may have been volcanic rift eruptions. As discussed below, the ridge is cut on its north and south edges by ice and water erosion from later Hesperian (and Amazonian) fluvio-glacial events (Fig. 7A). A volcanic origin of the ridge, its location on the floor of Kasei, and age lead us to suggest that Uranius Dorsum marks the end of the first volcanic cycle within the study area.

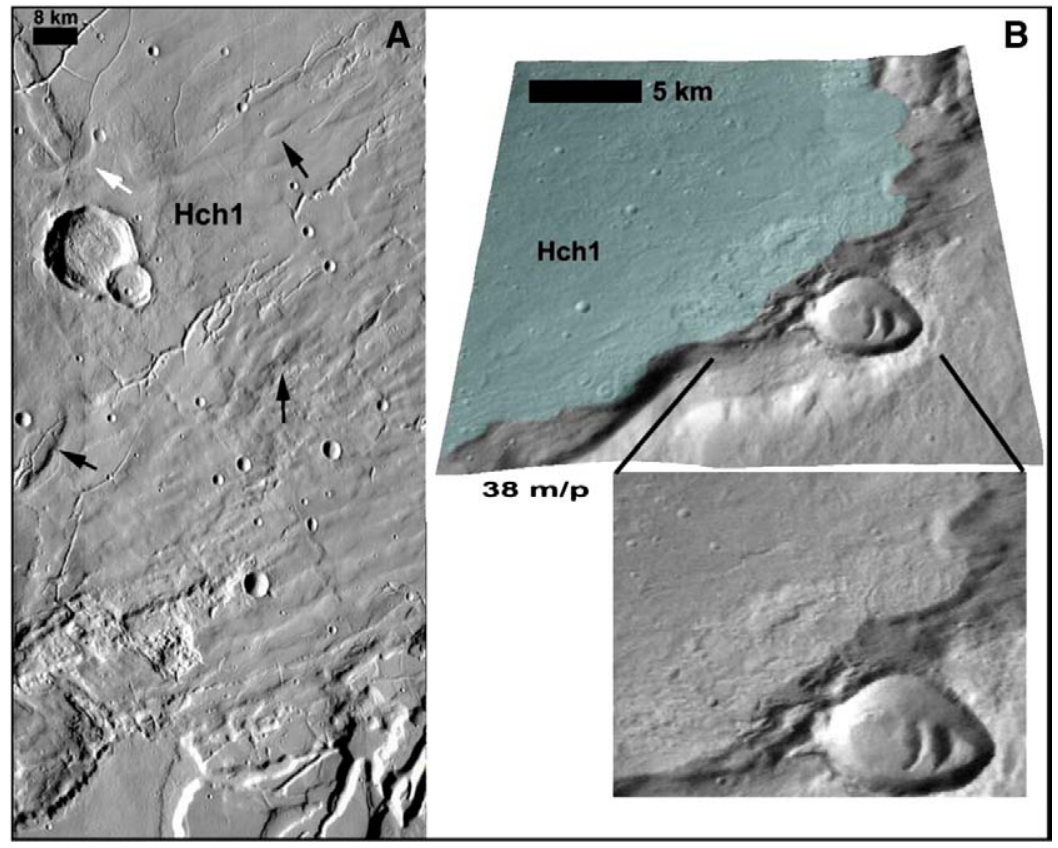

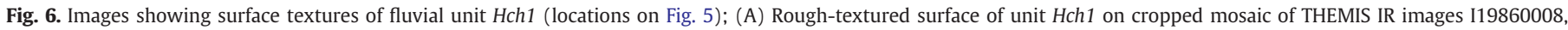

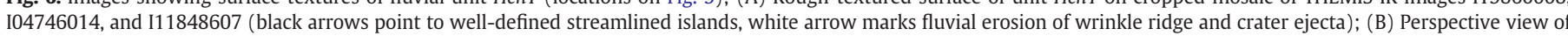
HRSC 1612_0000 showing thick Hch1 deposit within ancient impact crater basin. 


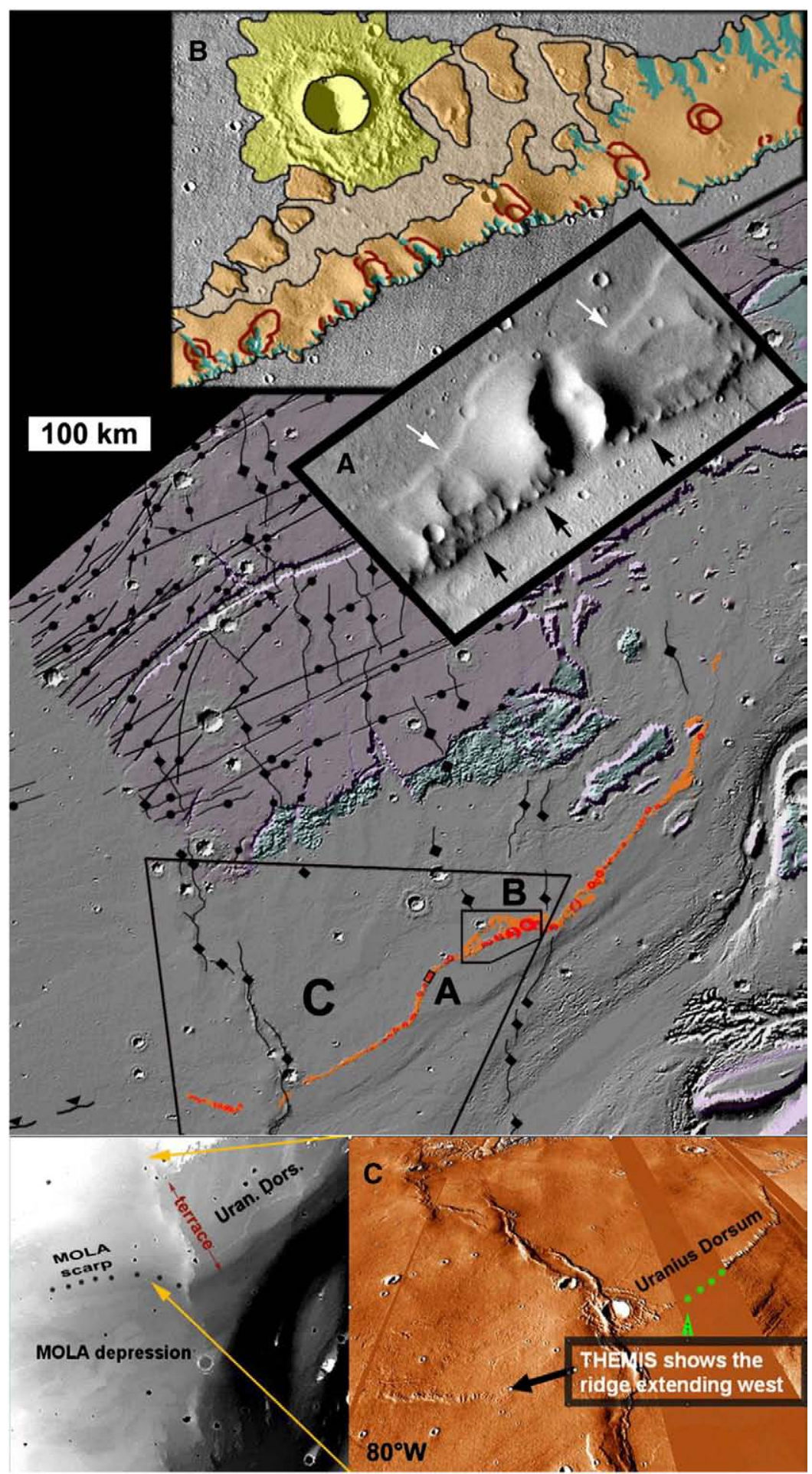

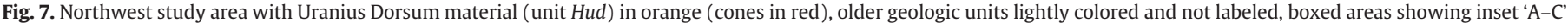

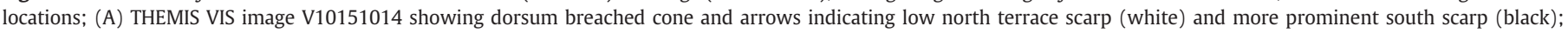

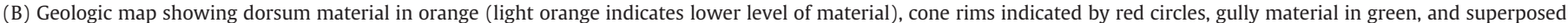
impact crater in yellow; (C) new mapped extension of ridge to $80^{\circ} \mathrm{W}$., north of a MOLA topography-detected depression on the flank of Tharsis.

After the emplacement of the Uranius Dorsum cratered cones at about $3.6 \mathrm{Ga}$, our crater count averages indicate an apparent $.2 \mathrm{Ga}$ cessation of activity within the study area. Activity resumes around $3.4 \mathrm{Ga}$, as all of the rest of the Hesperian materials have crater retention ages with overlapping error bars that date from this time period. Hence relative ages for these units are more strongly based on stratigraphic relations. The first of these materials appears to be the Hesperian Syria Planum Formation lower and middle members located about $800 \mathrm{~km}$ to the south of Uranius Dorsum on the plateau surrounding Echus Chasma. Rotto and Tanaka (1995) originally mapped 2 members of the formation: the lower and upper members. New data show at least 3 members of this formation on the Syria Planum plateau, now designated as the lower, middle, and upper members (units $\mathrm{Hsl}, \mathrm{Hsm}$, and $\mathrm{Hsu}$ ), respectively (Fig. 8). [This formation and the older-than-Tharsis-lava deposits (units $\mathrm{Hr}$ and $\mathrm{Hf}$ ) that surround Echus Chasma are still visible on the surface because the Fortuna Fossae highland, upslope on Tharsis, 


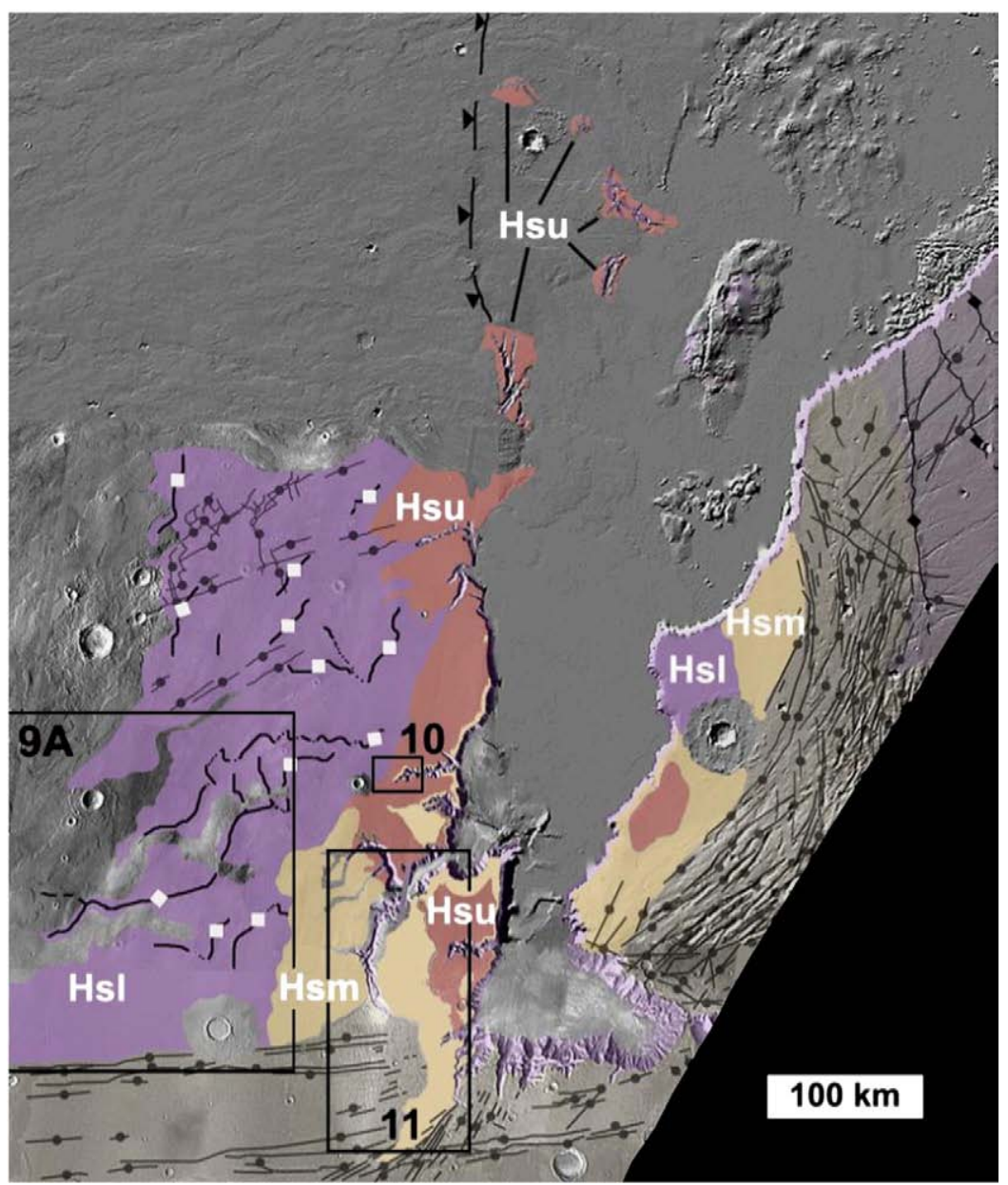

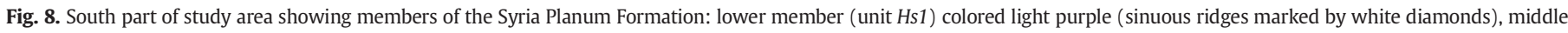

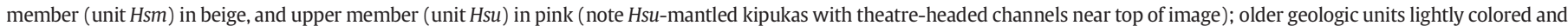
not labeled; boxed areas showing Figs. 9A, 10, and 11 locations.

protected the area from burial by younger Tharsis lava flows.] The Syria Planum Formation lower member (unit $\mathrm{Hsl}$ ) occurs west of the chasma. This material is unique in that it contains several broad sinuous ridges that trend roughly northeast (Fig. 8). The ridges are up to $12 \mathrm{~km}$ wide and $150 \mathrm{~m}$ high and are capped by very narrow ridges of more resistant material (Fig. 9; Zealey, 2007). Although unit Hsl embays and is therefore younger than Hesperian fractured material (unit $\mathrm{Hf}$ ), the sinuous ridges are cut in places by graben (Zealey, 2007). This relationship can be explained by our resurfacing ages of unit $\mathrm{Hf}$ that suggest graben were active in the Hesperian and then again later in the Amazonian. The unit's broad sinuous ridges have been interpreted as possible glacial eskers or sub-ice volcanic "tindar" ridges consisting of palagonitic material (Zealey, 2007, 2008). If this interpretation is correct, Hesperian glaciers or surface ice sheets may have been present in the Tharsis and Syria Planum regions along with volcanic activity, and we include these local putative volcano-ice interactions in the second volcanic cycle.

The Syria Planum Formation lower member is overlain by both the middle and upper members. Locally this contact is extremely sharp and forms a cliff behind which one or both horizons of the other members are observed (Fig. 10). Crater count data indicate that the middle member (unit $\mathrm{Hsm}$ ) was deposited around $3.42 \mathrm{Ga} \pm 0.9$ (Table 2). This dark albedo material appears relatively smooth on low resolution data sets and was not detected in Viking Orbiter images. New data show this unit to be found only on Syria and Lunae Plana, where it surrounds and is cut by Echus Chasma (Fig. 8). At MOC (R2001530) and HiRISE (PSP007654_1805) scales the unit appears to be formed of layered materials eroded into small mesas and plateaus. Using HRSC topography, we estimate the current thickness of unit
Hsm to be about $100 \mathrm{~m}$. Narrow valleys fed by even narrower sinuous dendritic channels can be observed cutting into the unit (Fig. 11). However our crater retention dates indicate that the resurfacing (channeling) of this unit took place somewhat later than deposition. The channeling and subsequent eolian erosion have formed the unit's small mesas and plateaus. The nature of unit Hsm- a heavily eroded $100 \mathrm{~m}$ thick, layered deposit, with layers that are both bright and dark and that do not show any geomorphological indications of volcanic flows- leads us to suggest that the material is a somewhat friable layered sedimentary rock. We interpreted it as possible volcanic ash (some layers may be partly-lithified) that was deposited in at least the east-central Tharsis area. This possible Hesperian ash material may have been much more widespread, as its mostly eroded outcrop area is now limited to what is left unburied by Tharsis lava flows and not yet removed by the wind. Deposition of this material marks the end of the second volcanic cycle in the field area.

During the emplacement time of the Syria Planum Formation and $800 \mathrm{~km}$ to the north, Uranius Dorsum was eroded to form north and south trending gullies that can be observed to cut the ridge (Fig. 7B). The shallow U-shaped valley cross-section suggests possible erosion by small ancient glaciers that may have covered this cratered-cone ridge (Fig. 7B). This glaciation event combined with the possible glaciation (perhaps occurring nearly simultaneously) on the lower member of the Syrian Planum Formation mark the onset of the second fluvio-glacial period within the study area. After their formation, the gully fronts (debouchment areas) and the north side of Uranius Dorsum were truncated. [Presumably the truncating erosion also occurred on the south edge of Uranius Dorsum, but there it is over printed by a larger 


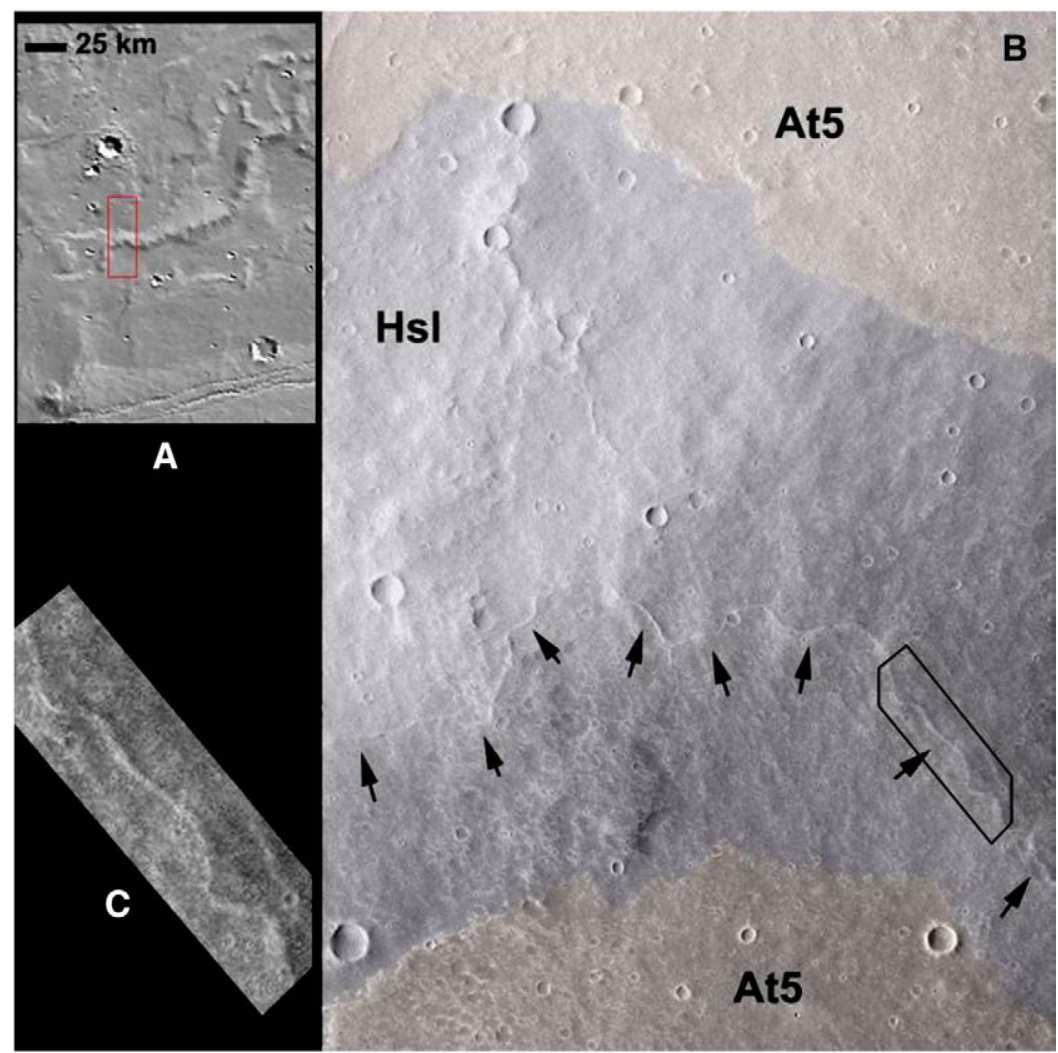

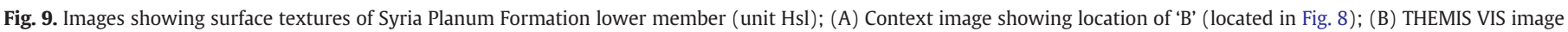

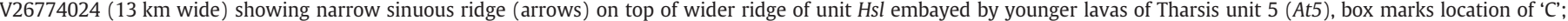
(C) enlarged view of narrow sinuous ridge.

later Amazonian flood erosion scarp (black arrows, Fig. 7A).] This truncation has resulted in a low cliff (marked by white arrows on Fig. 7A) that is locally observed abutting floor material unit Hch2 (Fig. 12) and embayed by younger Hesperian lavas (Figs. 13 and 14). The area of the gullies is quite small, but one of our crater counts indicate an age of $3.4 \pm 0.7 \mathrm{Ga}$ (Table 2), which is consistent with their embayment by younger Hesperian lavas (units $\mathrm{Ht2}$ and $\mathrm{Ht}$, see below).
The flat-floor material that lies on either side of the dorsum is the caprock of an upper terrace of Kasei Valles now apparent on MOLA topography (Figs. 7C and 13B) and new high-resolution image data sets (Fig. 12). The terrace material does not appear to display the typical surface characteristics of lava flows and is in places carved by grooves from later flooding. Locally it is associated with east-trending streamlined mounds or islands observed in northeast Kasei Valles

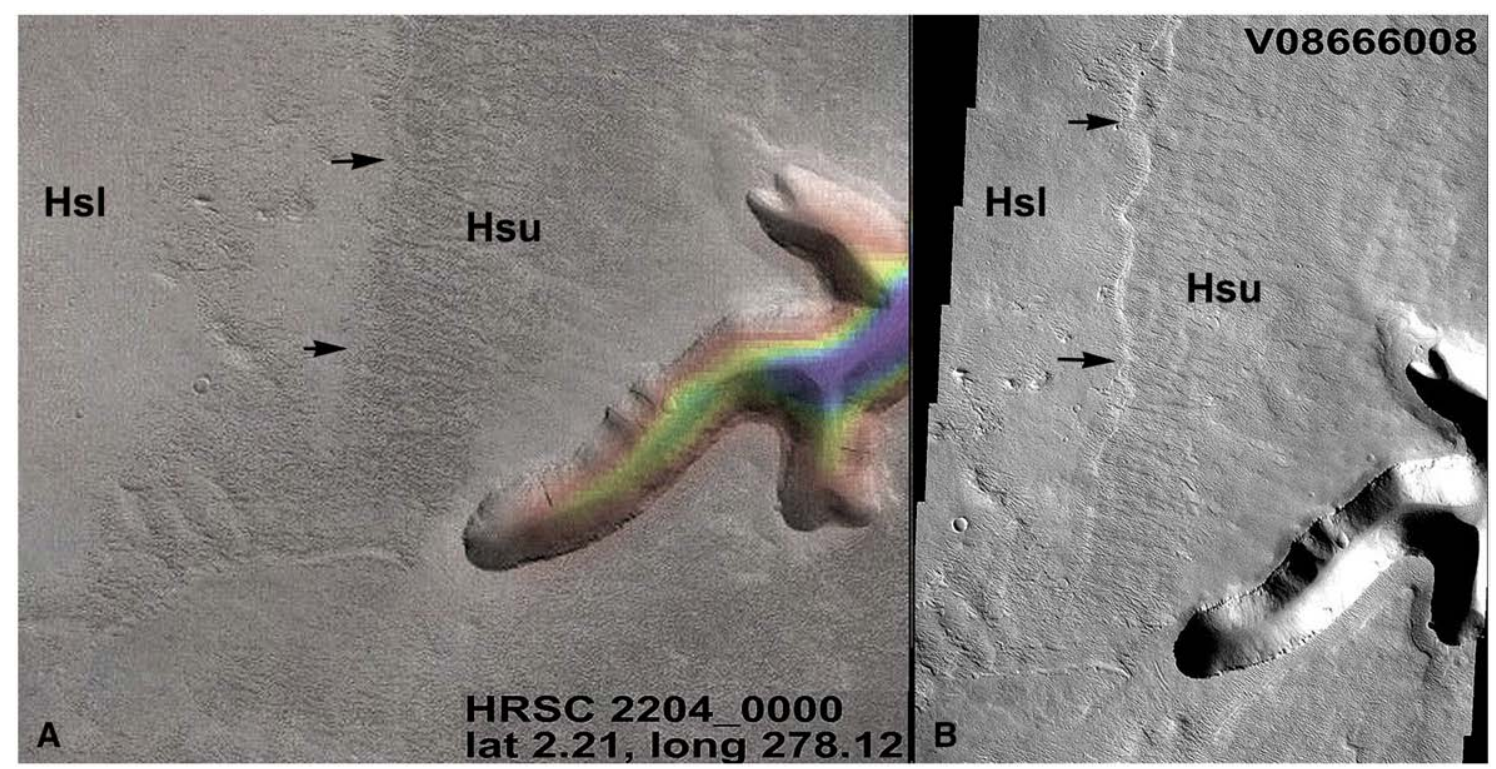

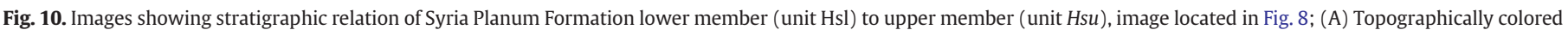
(purple $=$ low) HRSC image showing cliff (arrows) marking edge of overlying members (Hsm and Hsu); (B) THEMIS VIS image showing area details. 


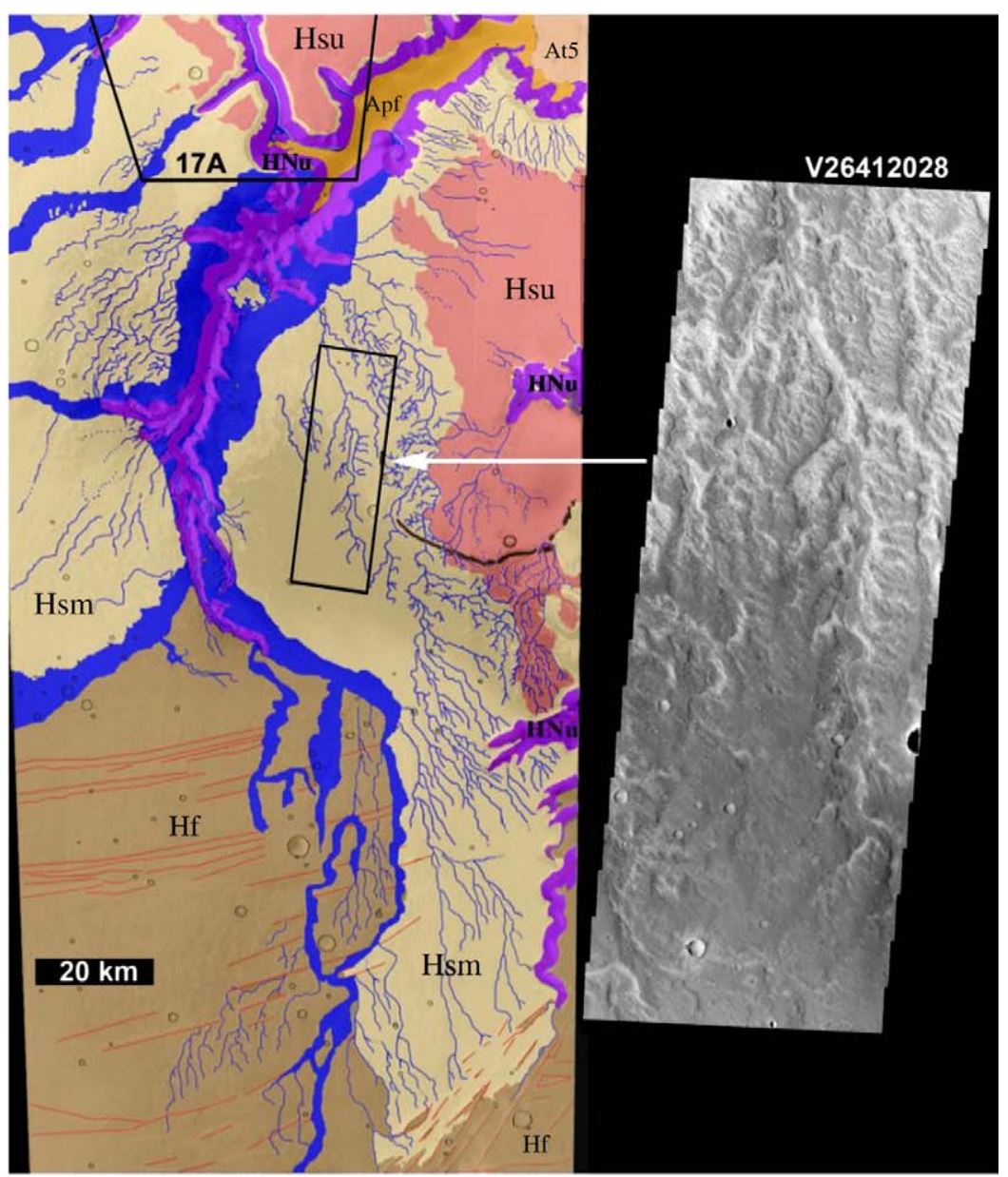

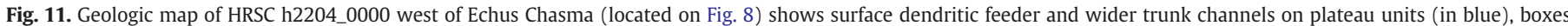

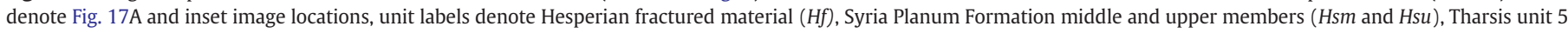
(At5), and Amazonian platey flow material (Apf); (Inset) THEMIS VIS image V26412028 showing narrow dendritic channels on middle member (unit Hsm).

(shown in green on Fig. 12). We have designated this terrace as unit Hch2. Hesperian lavas (discussed below) were subsequently deposited on this flat-floor material. The local streamlined mounds on this floor terrace are also embayed by these younger lavas (Fig. 12). Lavas, especially fluid flood lavas, flow rapidly down slope following topographic lows, and therefore the eroded flat-floor material underneath the overlying lavas had to exist before their deposition. This floor material is visible in an east-trending swath south of Uranius Dorsum (Fig. 12A) and in some moated areas that surround the Tempe Terra plateau and smaller outlying mesas (Fig. 12B). The surface of the material is dated by cumulative crater counts ranging from 2.49 to $3.48 \mathrm{Ga}$ (Table 3 ), but as the unit is heavily eroded and underlies an aerially extensive lava dated as $3.38 \mathrm{Ga}$ (unit Ht2, see below), its inferred stratigraphic age is probably closer to $3.4 \mathrm{Ga}$. The upper terrace is the highest topographic level of the north Kasei Valles floor. Based on the floor material's association with the truncation of Uranius Dorsum and streamlined islands (Fig. 12C), its occurrence on the high terrace of the Kasei floor, the outcrop trend, and stratigraphically inferred age, we interpret this material to be the result of another flooding event sourced from Tharsis and within the region's fluvio-glacial cycle 2 . Hch2 is a mostly erosional unit, but in places it is observed to form a distinct layer (Fig. 12A). Ice and or floods of this event were no doubt responsible for additional carving of the west-east trend of Kasei's route to Chryse Planitia. Unit Hch2 is eroded to various extents by later Amazonian floods (Fig. 12A), as are all of the materials on the floor of Kasei Valles.

Unit Hch2 and Uranius Dorsum are partly overlain and embayed by lavas of two members of the Hesperian Tharsis Montes Formation
(Figs. 13 and 14). The eruption and subsequent deposition of these two members constitute the beginning of the third volcanic episode in the study area. Member 2 (unit Ht2) occurs in the northwest part of the study area, where it infills graben and rift troughs on Tempe Terra (such as Labeatis Fossae) and partly buries unit Hch2 on the Kasei Valles floor (Fig. 13). Lobate flow fronts, typical of lava flow morphology, can be observed within the unit (Fig. 14). Member 2 has an average absolute crater age of $3.38 \mathrm{Ga} \pm 0.76$ and it is overlain by member 4 (Table 3 ). East of Fesenkov impact crater, secondary craters derived from this impact event can be observed on the surface of unit Ht2, but these craters are not observed on the overlying member 4 (Fig. 15), indicating a passage of time between depositions of the two members. Unit $\mathrm{Ht} 2$ is also unique in that for over $250 \mathrm{~km}$ the surface of the material displays a narrow leveed ridge that splits and rejoins (Fig. 16). Although the feature could be a medial glacial ridge or esker, we interpret it to likely be a lava tube because of its location central to a lobate-margined flow and the rejoined splits similar to terrestrial lava tubes such as: Lava River and Slate Cave lava tubes in the San Francisco lava field of northern Arizona (M. G. Chapman, pers. note), Suswa lava tube in Kenya (W1), and Ka'eleku Cavern in Hawaii. Lava tube speleologists refer to these splits as braided mazes (W2 and Bunnell, 2008). If it is a lava tube, the roof has not collapsed and it is only locally buried by lava. Therefore it could be surface tube with local areas of semi-trench or interior tube types (Harter and Harter, 1979). This putative lava tube is extremely long compared with terrestrial examples. Lava tubes are feeder channels for flood lavas and as lavas drain out, they tend to form vacant tunnels that could possibly provide shelter for future explorers (Hörz, 1985). Unlike the few other lava tubes identified on Mars, this tube is more accessible, as it is not 


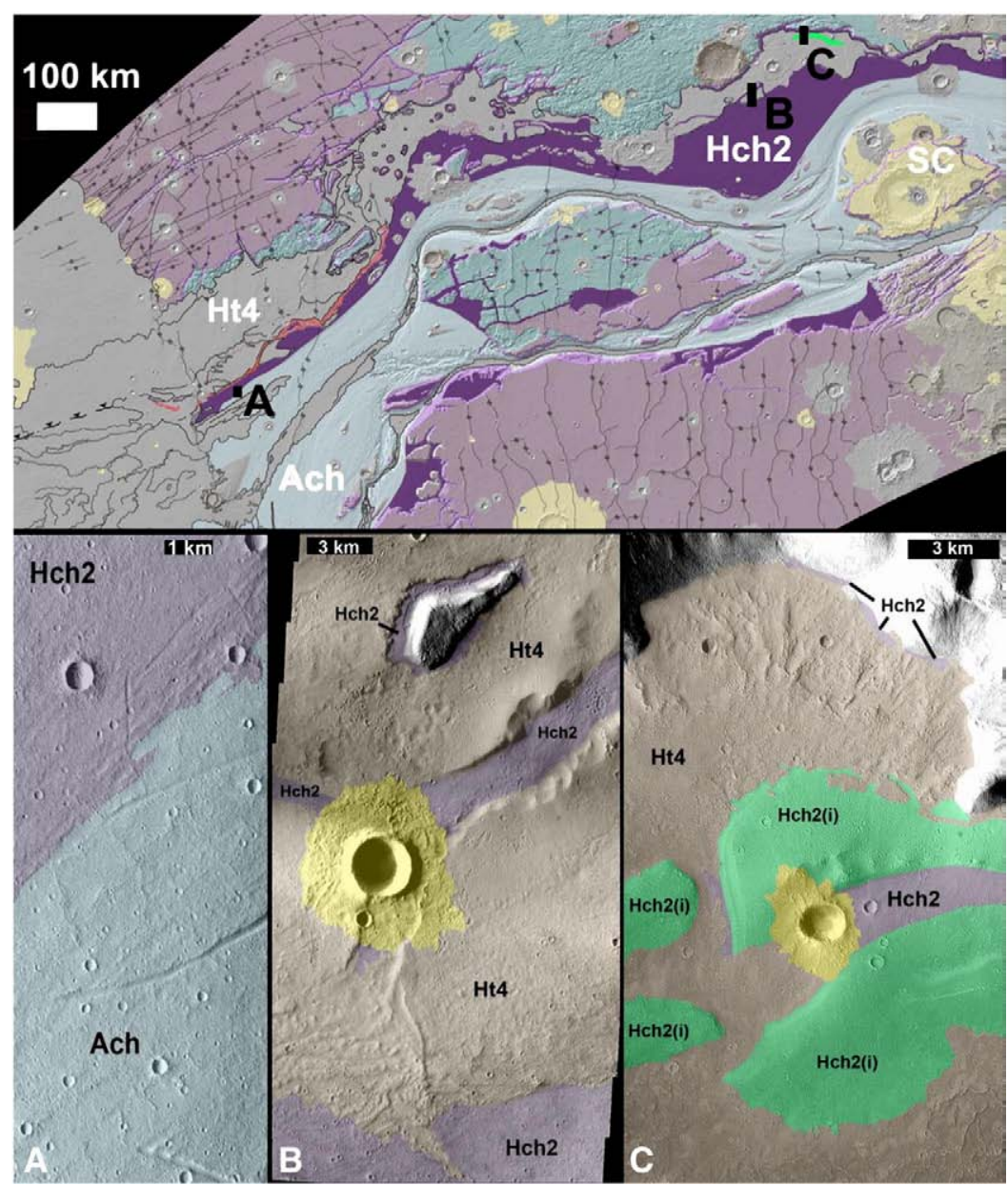

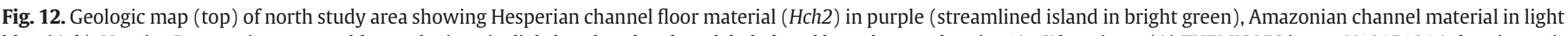

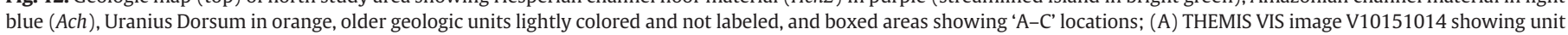

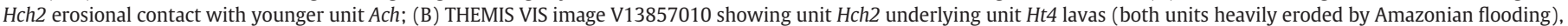

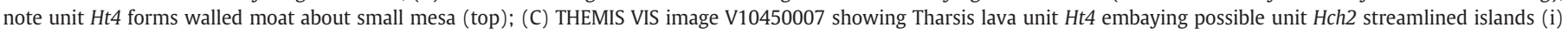
mounds (green).

located on top of the Tharsis volcanoes with access only through enormously deep skylights formed by roof collapse (Cushing et al., 2007).

The overlying Tharsis Montes Formation member 4 (Ht4) was previously considered to be Amazonian in age (Scott and Tanaka, 1986), however our new crater counts indicate that member 4 is Hesperian in age ( $3.37 \mathrm{Ga} \pm 0.87$; Table 3 ). The unit only outcrops in a $1200-\mathrm{km}-\mathrm{long}$ east-trending belt from Fesenkov to Sharonov impact craters (marked FC and SC on Fig. 13A). Lobate terminations on and within the flow and its traceability to the flank of Tharsis support the previous interpretations that the unit is lava flow material. Remnant ice from earlier Hesperian floods or accumulation from possible snow fall (as suggested by Hauber et al., 2008) may have been present on the north Kasei surface at the time of unit 4 deposition, as unit $\mathrm{Ht} 4$ forms walls about moats that surround the cliffs of the Tempe Terra plateau and small mesas that are outlying plateau remnants (Fig. $12 \mathrm{~B}, \mathrm{C}$ ). The moats were interpreted to mark the position of ice-rich lobate debris aprons around the mesas and the plateau equatorward of $30^{\circ}$ latitude (Lucchitta and Chapman, 1988; van Gasselt, 2007; Hauber et al., 2008). The Ht4 lavas flowed east toward Chryse Planitia, on a path down the valley cut by the earlier Tharsissourced floods (Fig. 13). Units $\mathrm{Ht} 2$ and $\mathrm{Ht} 4$ were initially Hesperian lowlying Kasei-valley-floor lavas, but now they form inverted topography and are located on the highest terrace (the Hch2 terrace) of north Kasei Valles (Fig. 13B). The Ht4 unit is eroded on its south edge and along down-valley outcrops by later Amazonian floods that carved the next and lower east-trending terrace level into north Kasei Valles (Fig. 13). Although we can trace this moat-forming unit far to the east, its eastern downstream eroded areas have crater retention ages that overlap those of the Amazonian floods (see van Gasselt, 2007; Hauber et al., 2008) and therefore these younger ages are likely due to resurfacing by later erosion. Near the eastern most distal outcrops of member Ht4, is the Sharonov impact crater (formed by a bolide that impacted into a mesa carved in north Kasei Valles). The ejecta overlies the high topographic terrace level occupied by channel unit Hch2 and lava unit member Ht4 (Fig. 13). However, the distal ejecta on the floor of Kasei Valles were eroded by later Amazonian floods. Although our crater counts date the surface of the impact crater to about the same age as member 4, likely it occurred after emplacement of this lava unit.

At about this same time in the Hesperian, but $800 \mathrm{~km}$ to the south, water was beginning to be released into the proto-Echus Chasma via numerous narrow dendritic surface channels that are carved into the Syria Planum Formation middle member (unit $\mathrm{Hsm}$ ). These small channels occur on the surface of the middle member on the Syria and Lunae Plana directly west, northwest, and northeast of the chasma (Fig. 11; Ansan et al., 2007, 2008). We date the cutting of the channels to have taken place around $2.9 \mathrm{Ga} \pm 0.26$ by crater counts of the channeled surface area (Table 4), but as the channeled surface is clearly overlain by the Syria Planum Formation upper member (see unit Hsu below), the channeling must have occurred about 3.4 Ga (Figs. 11 and 17A). Our crater retention age of the channeled surface is much younger and this data may reflect crater erosion (narrow channels may be preferentially indurated by fluid transported cements). Perhaps not unexpected, the narrow channel surface has an Amazonian resurfacing age that overlaps 


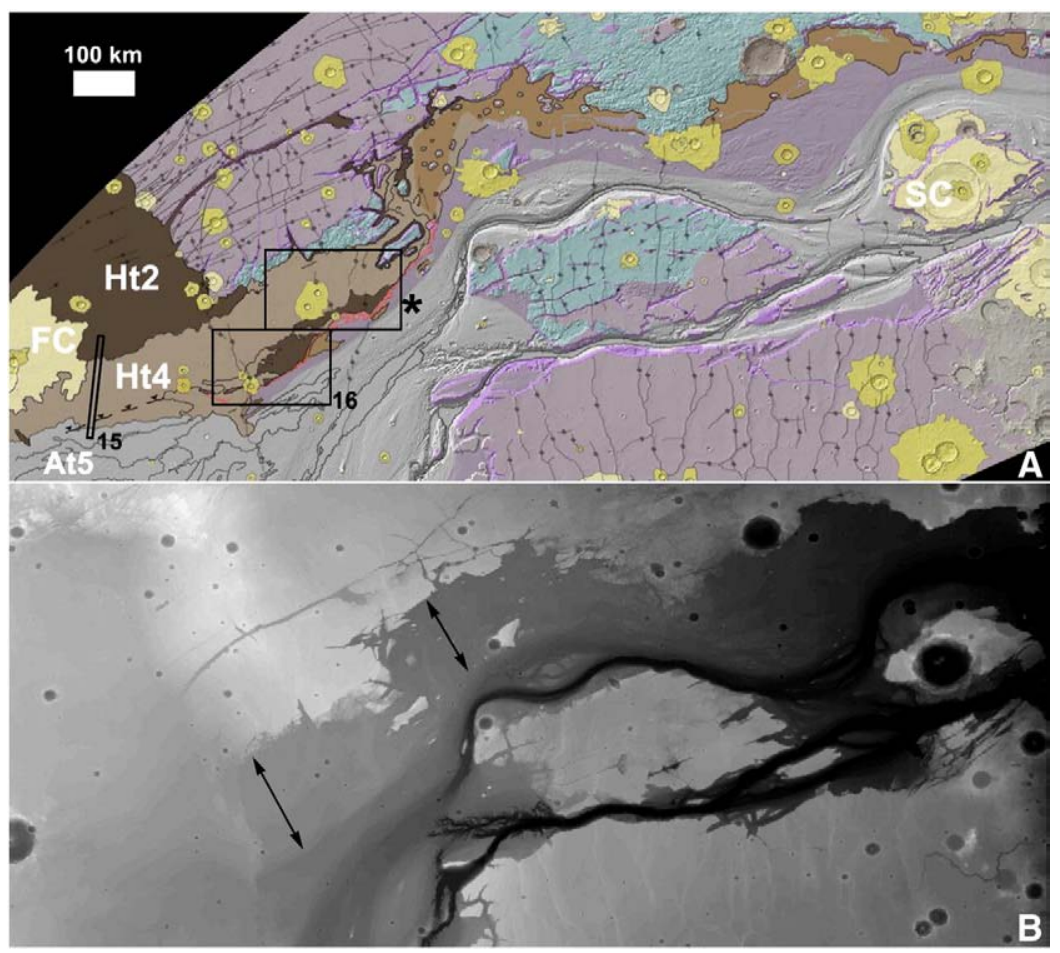

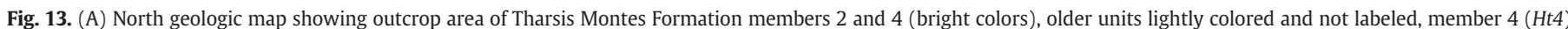

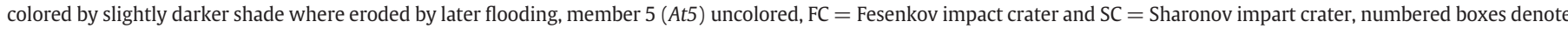

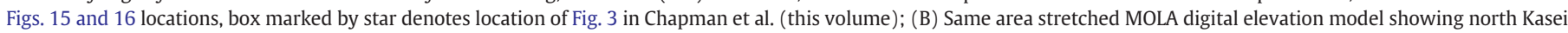
Valles upper terrace between arrows.

the average ages of Amazonian flood episode 3 and volcanic episode 4. It is possible that the younger crater age of this surface may be just a testament to the extremely widespread resurfacing effects of the voluminous Amazonian flood lavas and catastrophic fluid floods in the study area. The shallow dendritic channels are covered by an eolian infill of dune forms that outlines the valley floors (Mangold et al., 2004) and prevents any observation of deep inner channel floors to calculate discharge rates. The valleys are sinuous and organized with up to 5 orders of connections without any braided areas. These dendritic connections

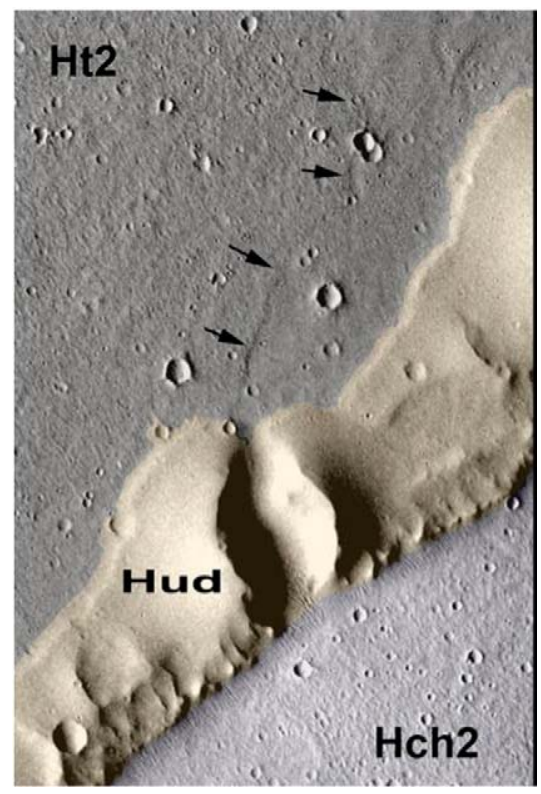

Fig. 14. THEMIS IR images I17801017 and I18113018 colored mosaic displaying Uranius Dorsum cratered cone ( $3 \mathrm{~km}$ wide) and associated volcanic and fluvial units; arrows mark lobate lava flow termination of embaying unit Ht2, location same as Fig. 7A. indicate low discharge rates, and HRSC DEM topography shows that shallow valleys follow the current topography (Ansan et al., 2007). The channels appear to have drained into the Echus Chasma and Upper Kasei area through wider trunk channels, supporting the interpretation that a

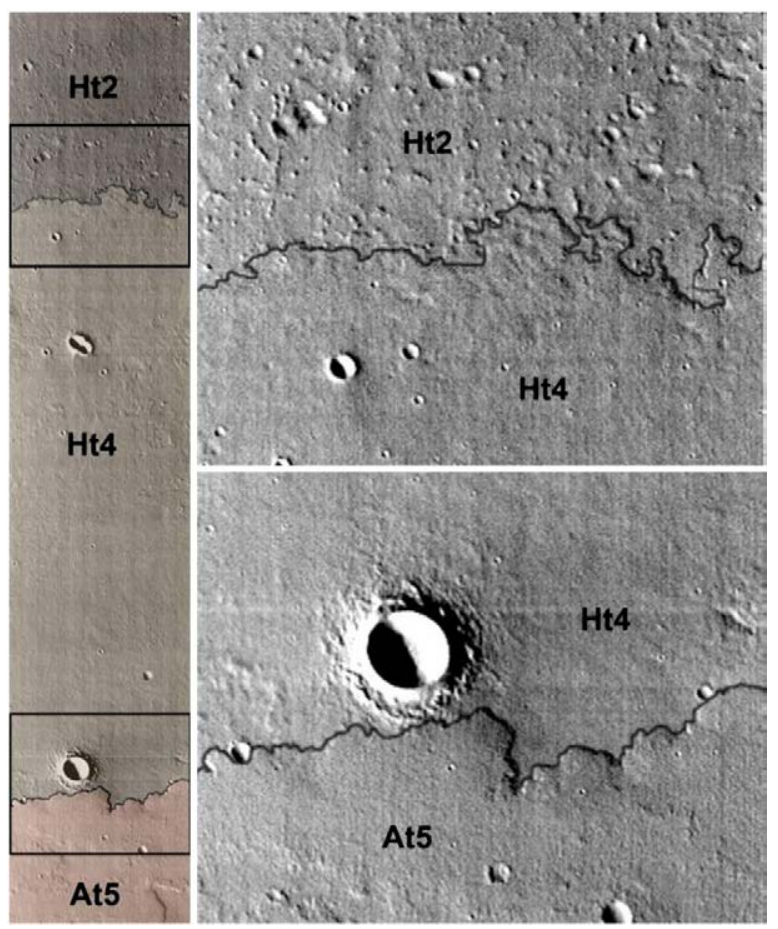

Fig. 15. THEMIS IR image I17639016 showing Tharsis Montes Formation member stratigraphy in study area (boxed areas enlarged on right); (upper right) enlargement shows secondary craters from Fesenkov impact crater (marked 'FC' on Fig. 13) on unit $\mathrm{Ht} 2$ surface overlain by unit $\mathrm{Ht} 4$; (lower right) enlargement shows blunt and steep flow terminations of overlying unit At5; location on Fig. 13. 


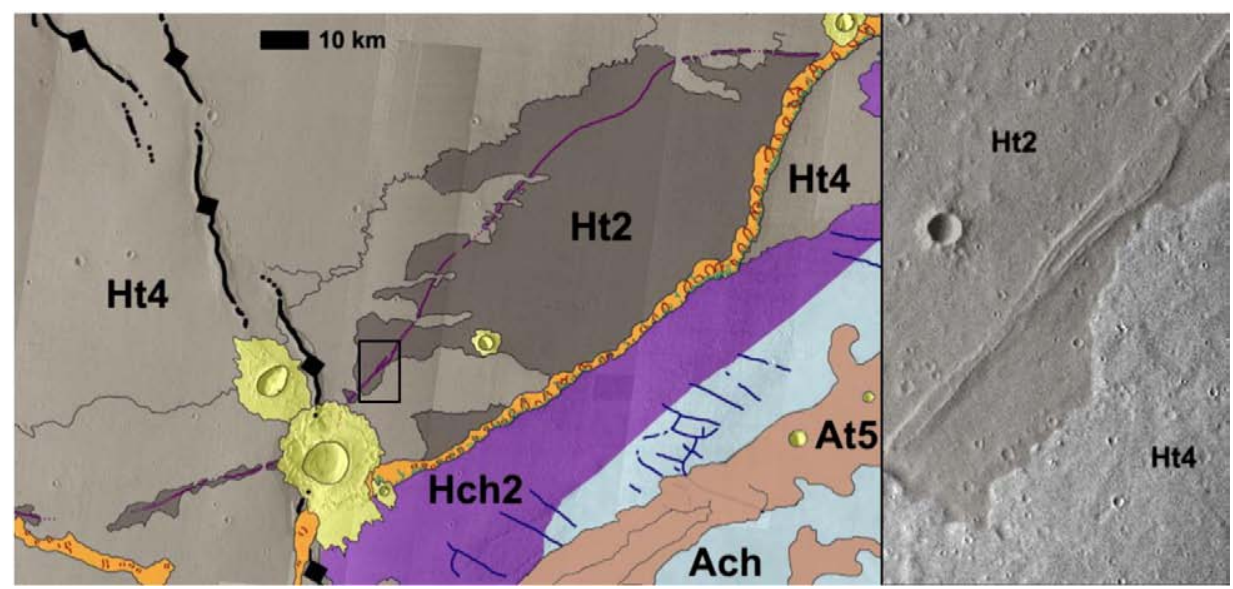

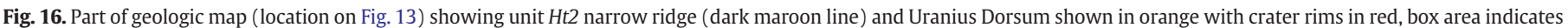
location of THEMIS VIS image V22768011 (right) displaying narrow ridge details.

proto-Kasei depression had already formed via early Hesperian fracturing. Valley heads are scattered at watersheds boundaries as expected for surface runoff (Mangold et al., 2008). Although the floors are partly filled with relatively thin eolian deposits, valley walls appear to have a V-shape profile typical of fluvial processes with valley depth between 20 and $100 \mathrm{~m}$. However, wider main trunk valleys have a straight longitudinal profile devoid of apparent concavity, which suggests a limited evolution. This geometry gives us some information about the duration of valley formation. Terrestrial analogs indicate that sustained fluvial erosion is required to explain the geometry of these valleys and maturity of the networks, which is in the range of a few thousands of years for these $10 \mathrm{~s}$ of-meters-deep valleys (Mangold et al., 2008). This is a minimum because valley network will not continue to evolve in 2D geometry after maturity is reached. However, valleys will continue to evolve in 3D geometry, with longitudinal profiles becoming more and more concave. Since the longitudinal profiles are poorly concave compared to terrestrial examples of evolved valleys, this shows a rather limited evolution after maturity (i.e. timescales of several millions of years are not realistic). Observations
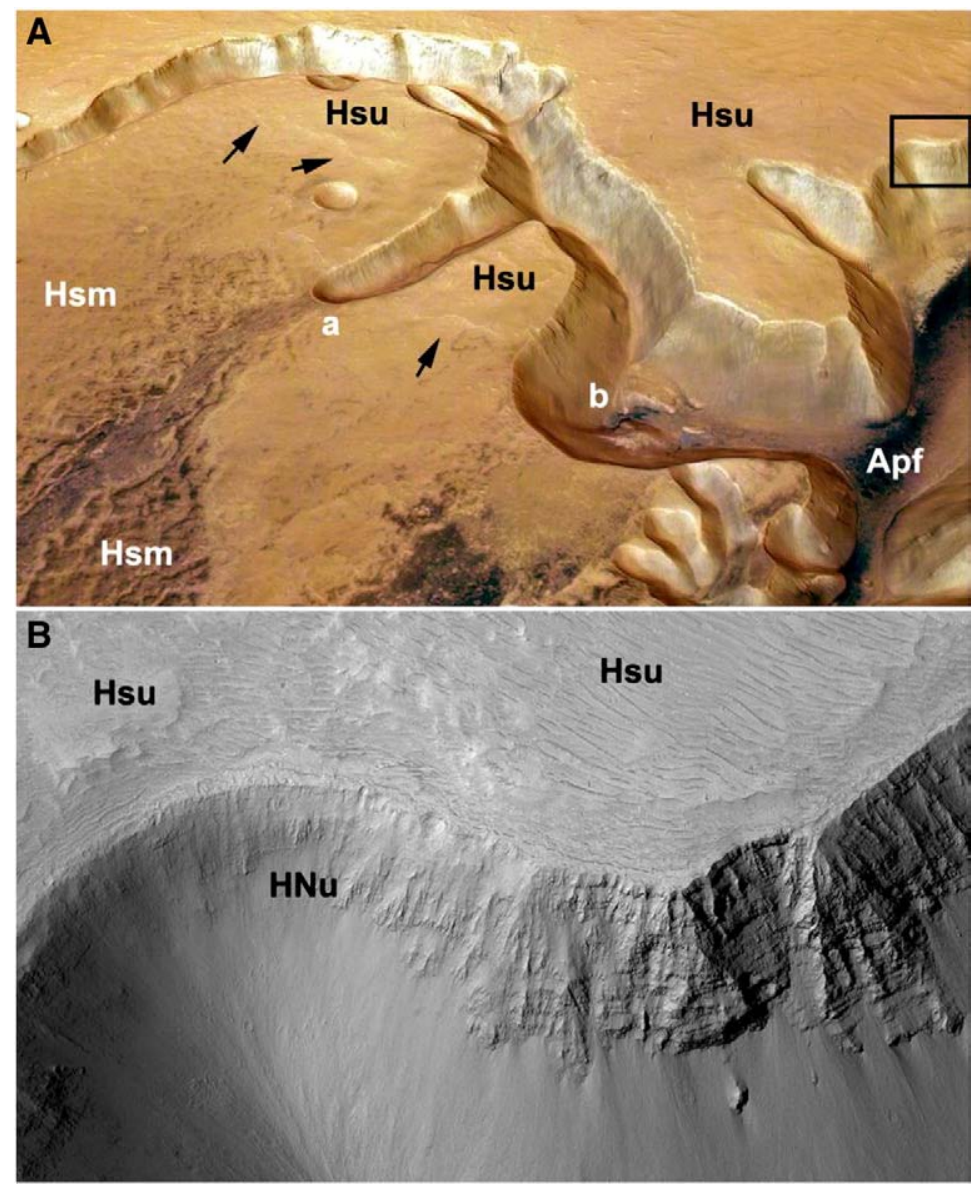

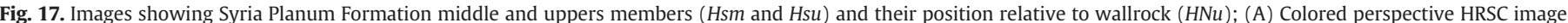

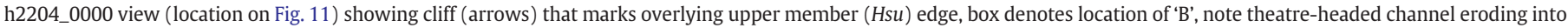

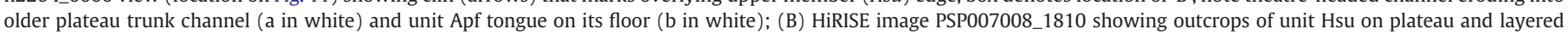
wallrock material of unit $\mathrm{HNu}$ (Hesperian-Noachian material, undivided). 
at HRSC full resolution and at MOC scale show that the shallow valleys are cut into the dark albedo unit $\mathrm{Hsm}$ that lies over unit $\mathrm{Hsl}$ on the plateau. Similar to terrestrial analogs, if the valleys incise about a few tens of meters on unit $\mathrm{Hsm}$, the incision might have taken away as much material as 50 to $100 \mathrm{~m}$ in average--indicating low discharge rates analogous to terrestrial river systems with high water to rock ratios (values $>100$ ), suggesting that there may have been more than 100 times more water volume than material eroded through fluvial processes (Mangold et al., 2008). Such values require a large quantity of water (a minimum equivalent column of 5 to $10 \mathrm{~km}$ ), thus indicating a cycle of water circulation rather than a single episode. [However, if Hsm is ash material, incision rate is also dependent upon lithification state (i.e. poorly lithified ash erodes faster than indurated tuffaceous rocks).] At present the eroded outcrop area of the middle member is about $30,000 \mathrm{~km}^{2}$ and the channel density (similar throughout the Hsm surface) is about 9.2\%, which would comprise a channel-eroded area of about $2760 \mathrm{~km}^{2}$ over the entire unit. If we assume the valleys are about $30 \mathrm{~m}$ deep, erosion into lithified rock may have removed about $82 \mathrm{~km}^{3}$ of material, requiring a water volume of $8280 \mathrm{~km}^{3}$. This value has to be a minimum water volume, as there is no way to calculate an estimate of the entire amount of water from an unknown original (non-eroded) outcrop area. The amount of time required for the maturity of the network (as long as 10,000 yr) might be enough to invoke this amount of water. These valleys are the observational record of an episode of fluvial activity whose origin might not be directly connected with the Kasei Valles outflow channel formation, but whose channels contributed water into the Valles system, perhaps by ponding in the proto-Echus Chasma depression, if this trough was not yet breached to the north. The water that carved these channels may have come from subterranean sources within unit $\mathrm{Hsm}$, volcanic-induced melting of hypothetical Tharsis surface ice sheets (see discussion of unit $\mathrm{Hml}$ ), or climate change precipitation induced by local volcanic activity that lasted at least a few thousand years. The outcrop area affected by this narrow channeling is now limited to the area around Echus Chasma, but it could have occurred from here to areas farther north; all along the west edge of Kasei Valles now buried by younger lavas (small kipukas with theatre-headed valleys farther north support this conclusion; see Fig. 8). Because of the current limited aerial extent of the narrow channeling, the erosion may not have been widespread throughout the area. However, this could be an incorrect assumption if these channels did lie along the entire length of the west Kasei. This channeling is included in the hydrologic events of the second fluvio-glacial period.

Unit Hsm and its dendritic channels are overlain by the upper member of the Hesperian Syria Planum Formation (unit Hsu; Fig. 11). Unit $H s u$ has an average absolute crater retention age of $3.37 \mathrm{Ga} \pm .8$, an age range that overlaps the underlying middle member hence both units were likely deposited relatively close in time. The contact between the 2 members is located at the base of an observable scarp or cliff, which marks the edge of the overlying Hsu member (Fig. 17A). Where the Hsu member is thick, it completely buries the dendritic channels (Fig. 17A). However, where it is heavily eroded, parts of underlying dendritic channels can be observed through a thin mantle of $\mathrm{Hsu}$. Like the middle member (unit Hsm), the upper member is a layered material. The cliffs surrounding Echus Chasma have cut into the unit (Fig. 17B) and locally it appears to have been eroded by the wind, and hence it is fairly friable material in relation to the surrounding plateau lava flows. The material is found now only on Syria and Lunae Plana and also on kipukas farther north on the west edge of Kasei Valles (Fig. 8). Although the original depositional area may have been much more widespread, the units present outcrop area is now limited to what is left unburied by lava flows and not yet removed by wind. It is interpreted to be another possible partly-lithified ash material that was deposited in the east-central Tharsis area after the eruption of the Tharsis Montes Formation member Ht4. The deposition of unit Hsu marks the end of the third volcanic episode in the study area. After deposition of unit Hsu the rest of the upper Hesperian was a very quiet time in the Echus Chasma-Kasei Valles area, with no major geologic materials deposited until later in the Amazonian system.

\section{Conclusion}

Our new mapping and crater count results suggest that between the early Hesperian and late Hesperian the study area was affected by at least 3 episodes of widespread volcanic activity and 2 periods of episodic fluvio-glacial activity (Fig. 18). These activities took place largely between 3.7 to $3.6 \mathrm{Ga}$ and then again around $3.4 \mathrm{Ga}$. The first volcanic episode to affect the area was the deposition of flood basalts that formed the Hesperian ridged plains (unit $\mathrm{Hr}$ ) at about $3.7 \mathrm{Ga}$.

Unit $\mathrm{Hr}$ was fractured during the formation of Echus Chasma around 3.6 Ga (closely spaced graben are mapped as unit $\mathrm{Hf}$ on Figs. 1 and 4 ). This type of fracturing farther north may have released subsurface floodwaters of the first fluvio-glacial cycle in the area, as the east-trending Tharsis-sourced floods can be traced to a Tempe Terra rift. Geomorphic surface remnants of the flood are now marked by streamlined islands, pit chains, and grooves that occur on the high plateaus surrounding north Kasei Valles. We designate this surface as unit Hch1, and our crater counts date this flooding to have occurred about $3.6 \mathrm{Ga}$ as well. Because evidence of the flood erosion occurs about $1 \mathrm{~km}$ higher than the current elevation of Kasei Valles on plateaus cut by the valley, obviously the initial erosion predated the current configuration of the valley floor. However, continued floods from this cycle may have contributed to erosion of the east-trending part of the north Kasei Valles floor.

Subsequent Hch1 flooding (and/or some other process) must have formed the north Kasei valley floor close to this time because our oldest material unit on the valley floor composes the Uranius Dorsum ridge and it also has an average crater retention age around 3.6 Ga. In other words,

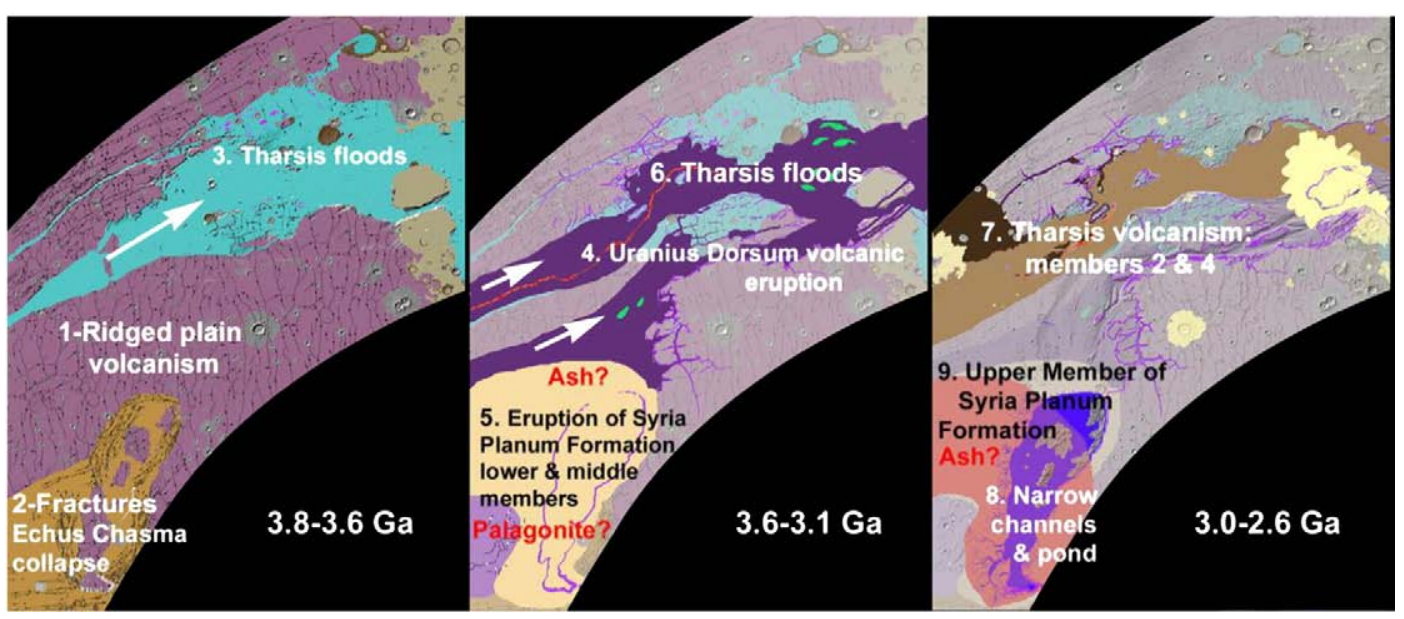

Fig. 18. Illustrations showing historical scenario of major Hesperian-age geologic units in study area. 
the location of the ridge on the floor of Kasei Valles indicates that the valley floor had to have formed between the time of initial Hch1 flooding of the plateaus and the emplacement of the Dorsum. This ridge consists of 58 aligned cones and associated deposits that we interpret as likely volcanic material from fissure eruptions. The ridge follows the trend of the Tempe, Mareotis, and Sacra Fossae rift systems that occur around the north end of Tharsis on Tempe Terra and north Lunae Planum. Upwelling magmas may have fractured unit $\mathrm{Hr}$, created graben (both around Echus Chasma and the northern Tharsis rift systems), and released floodwaters. Continued magma rise may have erupted along at least one rift forming Uranius Dorsum. The emplacement of Uranius Dorsum marks the conclusion of our first volcanic episode in the study area.

Crater count data indicate that the second and third cycles of volcanic activity and the second cycle of fluvio-glacial activity all occurred around $3.4 \mathrm{Ga}$, hence their relative ages are determined largely by stratigraphy (Fig. 18, Tables 2, 3, and 4). Materials deposited during volcanic cycle 2 were the lower and upper members of the Syria Planum Formation deposited in south Kasei (around Echus Chasma). The lower member (unit $\mathrm{Hsl}$ ) may consist of possible glacial eskers or sub-ice volcanic "tindar" ridges consisting of palagonitic material, as it is associated with sinuous ridges (Zealey, 2007, 2008). At about this time in north Kasei Valles, U-shaped, presumably glacial gullies were cut into Uranius Dorsum. The middle and upper members of the Syria Planum Formation lack the ridges of the lower member and display lithologies that may be more consistent with an origin as widespread ash deposits. For perhaps at least $10,000 \mathrm{yr}$ prior to the deposition of the upper member, narrow dendritic channels were eroded into putative ash deposits of underlying middle member (unit $\mathrm{Hsm}$ ) and their waters drained into an early Echus Chasma depression. In north Kasei, another east-trending Tharsis-sourced flood around 3.4 Ga cut into Uranius Dorsum, truncated its U-shaped gullies, and further enlarged the relatively flat-floored path of the valley floor that turns abruptly east to Chryse Planitia in north Kasei Valles. We designate this flood material as unit Hch2. Our second fluvio-glacial cycle consists of the closely spaced in time $3.4 \mathrm{Ga}$ events that formed the putative glacial ridges in the lower member of the Syria Planum Formation, possible glacial gullies in Uranius Dorsum, unit Hch2 flood materials in north Kasei Valles, and narrow dendritic channels within the middle member of the Syria Planum Formation.

The third volcanic cycle in the field area began by eruption and deposition of flood lavas (also about $3.4 \mathrm{Ga}$ ) that covered a large area of the previous Hch2 flood path of north Kasei Valles, and embayed Uranius Dorsum. These flood lavas are mapped as member 2 (unit Ht2) and overlying member 4 (Unit Ht4) of the Tharsis Montes Formation. This volcanic cycle ended with the widespread ash deposit of the upper member of the Syria Planum Formation (unit Hsu). After deposition of unit $H s u$ the rest of the upper Hesperian was a very quiet time in the Echus Chasma-Kasei Valles area, with no major geologic materials deposited.

\section{Acknowledgments}

We are grateful to Dr. Stephanie Werner for her help with some of the preliminary crater counts. We would also like to extend our gratitude to Windy Jaeger and Ken Tanaka of the U.S. Geological Survey, and three unknown EPSL reviewers for their comments and contributions toward this manuscript. This research was partly supported by the German Science Foundation (DFG) through the Priority Program "Mars and the Terrestrial Planets" (DFG-SPP 1115, Project: Chronostratigraphy of Mars, grant: NE 212/8-3), by the Helmholtz Association through the research alliance "Planetary Evolution and Life", and by the German Space Agency (DLR), grant: 50QM0301 (HRSC on Mars Express).

\section{References}

Alt, D., 2001. Glacial Lake Missoula and its humongous floods. Mountain Press Publishing, Missoula, Montana. 197 pp.
Ansan, V., Mangold, N., Masson, Ph., Neukum, G., 2007. Topography of valley networks on Mars: Comparison between HRSC DEMs and MOLA data, Abstracts submitted to the Lunar Planet. Sci. Conf. 38th, \#1660.

Ansan, V., Mangold, N., Masson, Ph., Gailhardis, E., Neukum, G., 2008. Topography of valley networks on Mars from Mars Express High Resolution Stereo Camera digital elevation models. J. Geophys. Res. E7, E07006.

Baker, V.R., Milton, D.J., 1974. Erosion by catastrophic floods on Mars and Earth. Icarus 23, $27-41$.

Bunnell, D., 2008. Caves of Fire: Inside America. National Speleological Society. 124 pp. Chapman, M.G., Scott, D.H., 1989. Geology and hydrology of the north Kasei Valles area, Mars. Lunar Planet. Sci. Conf., 19th, Proceeds., part 1, pp. 367-375.

Chapman, M.G., Masursky, Harold, Scott, D.H., 1991. Geological maps of science study area 2, north Kasei Valles, Mars: U.S. Geol. Surv. Misc. Invest. Ser. Map I-2107, 1:5000,000-scale.

Chapman, M.G., Dumke, A., Hauber, E., Michael, G., Neukum, G., van Gasselt, S., Werner, S.C., Zuschneid, W., 2008. Geologic relations and possible origins of Uranius Dorsum. Abstracts submitted to the Lunar Planet. Sci. Conf. 39th, \#2212.

Christensen, P.R., Anderson, D.L., Chase, S.C., Clancy, R.T., Clark, R.N., Conrath, B.J., Keiffer, H.H., Kuzmin, R.O., Malin, M.C., Pearl, J.C., Roush, T.L., Smith, M.D., 1998. Results from the Mars Global Surveyor Thermal Emission Spectrometer. Science 279, 1692-1698.

Cushing, G.E., Titus, T.N., Wynne, J.J., Christensen, P.R., 2007. THEMIS observes possible cave skylights on Mars. Abstracts submitted to the Lunar Planet. Sci. Conf. 38th, \# 1371.

Harter, R., Harter, J.W., 1979. Geology of lava tubes. NSSAC Geology \& Biology Field Trip Guidebook, National Speleoogical Society, Huntsville, Alabama.

Hartman, W.K., Neukum, G., 2001. Cratering chronology and the evolution of Mars. Space Sci. Rev. 96 (376), 165-194.

Hauber, E., Kronberg, P., 2001. Tempe fossae, Mars: a planetary analog to a terrestrial continental rift? J. Geophys. Res. 104, 466-467.

Hauber, E., van Gasselt, S., Chapman, M.G., Neukum, G., 2008. Geomorphic Evidence for former lobate debris aprons at low latitudes on Mars: indicators of the Martian paleoclimate. J. Geophys. Res. 113, E02007. doi:10.1029/2007je002897.

Hörz, F., 1985. Lava tubes: potential shelters for habitats. In: Mendell, W.W. (Ed.), Lunar Bases and Space Activities of the 21st Century, Houston, Texas, Lunar Planet. Inst, pp. 405-412.

Ivanov, B.A., 2001. Mars/Moon cratering rate ratio estimates. Space Sci Rev. 96 (1), 87-104.

Jöns, H.P., 1990. Das relief des Mars:Versuch einer zusammenfassenden ubersicht. Geol. Rundsch. 79, 131-164.

Jöns, H.P., 1991. Interpretative analysis of the relief of the surface of Mars. Lithographisches Inst. Berlin, scale 1:30,000,000

Kehew, A.E., 1982. Catastrophic flood hypothesis for the origin of the Souris Spillway, Saskatchewan and North Dakata. Geol. Soc. Am. Bull. 93, 1051-1058.

Komatsu, G., Baker, V.R., 2007. Formation of valleys and cataclysmic flood channels on Earth and Mars. In: Chapman, M.G. (Ed.), The Geology of Mars: Evidence from Earth-based Analogs. Cambridge University Press, UK, pp. 297-321.

Lucchitta, B.K., 1982. Ice sculpture in the Martian outflow channels. J. Geophys. Res. 87 (B12), 9951-9973.

Lucchitta, B.K., Chapman, M.G., 1988. Ground ice along the northern highland scarp. MEVTV Workshop on early tectonic and volcanic evolution of Mars, Lunar Planet. Inst. Tech. Rept. 89-04, pp. 51-53.

Mangold, N., Quantin, C., Ansan, V., Delacourt, C., Allemand, P., 2004. Evidence for precipitation on Mars from dendritic valleys in the Valles Marineris area. Science 305 (5680), 78-81.

Mangold, N., Ansan, V., Masson, Ph., Quantin, C., Neukum, G., 2008. Morphometry and formation of fluvial landforms on North Valles Marineris plateau. J. Geophys. Res. 113 (E8), E08009.

Milton, D.J., 1974. Geologic map of the Lunae Palus quadrangle of Mars. U.S. Geol. Surv. Misc. Invest. Ser. Map I-894, 1:5,000,000-scale.

Rotto, S., Tanaka, K.L., 1995. Geologic/Geomorphic map of the Chryse Planitia region of Mars. U.S. Geol. Surv. Misc. Invest. Ser. Map I-2441, scale 1:5,000,000.

Scott, D.H., Carr, M.H., 1978. Geologic map of Mars, U.S. Geol. Surv. Misc. Invest. Ser. Map I-1083, 1:25,000,000 scale.

Scott, D.H., Tanaka, K.L., 1986. Geologic map of the western equatorial region of Mars, U.S. Geol. Surv. Misc. Invest. Ser. Map, I-1802-A, 1:15,000,000 scale.

Tanaka, K.L., Golombek, M., Banerdt, W., 1991. Reconciliation of stress and structural histories of the Tharsis Region of Mars. J. Geophys. Res. 96 (E1). doi:10.1029/ 91JE01194.

Tanaka, K.L., Chapman, M.G., 1992. Kasei Valles, Mars: interpretation of canyon materials and flood sources. Lunar Planet. Sci. Conf. 23rd Proceeds: Lunar Planet. Inst, pp. 73-86.

Tanaka, K.L., Skinner Jr., J.A., Hare, T.M., Joyal, T., Wenker, A., 2003. Resurfacing history of the northern plains of Mars based on geologic mapping of Mars Global Surveyor data. J. Geophys. Res. 108, E4. doi:10.1029/2002JE001908.

Tanaka, K.L., Skinner Jr., J.A., Hare, T.M., 2005. Geologic map of the northern plains of Mars. U.S. Geol. Surv. Misc. Invest. Ser. Map, I-2888, scale 1:15,000,000.

van Gasselt, S., 2007, Cold-climate landforms on Mars (PhD. Dissertation). Shaker Verlag, Aachen, Germany, 264 pp.

Werner, S.C. 2006. Major aspects of the chronostratigraphy and geologic evolutionary history of Mars (PhD. Dissertation, Freie University), Cuvillier Verlag, Göttingen, Germany, 153 pp.

Witbeck, N.E., Tanaka, K.L., Scott, D.H., 1991. Geologic map of the Valles Marineris Region, Mars. U.S. Geol. Surv. Misc. Invest. Ser. Map, I-2010, scale 1:2,000,000.

Zealey, W.J., 2007. Glacial, periglacial and glacio-volcanic structures on the Echus plateau, upper Kasei Vallis. 7th Internal. Conf. on Mars, Lunar Planet. Sci. Contrib. Rept. 1353, \#3002.

Zealey, W.J., 2008. Glacial, periglacial and glacio-volcanic structures on the Echus Plateau, upper Kasei Valles. Planet. Space Sci. 57 (5-6), 699-710. 